\title{
Echinoderm diversity in the Caribbean Sea
}

\author{
Juan José Alvarado
}

Received: 14 December 2009/Revised: 1 April 2010 / Accepted: 1 July 2010 /Published online: 22 July 2010

(C) Senckenberg, Gesellschaft für Naturforschung and Springer 2010

\begin{abstract}
The Caribbean is considered a unique biogeographic province, being one of the top five hotspots in the world for marine and terrestrial biodiversity. The echinoderm research on the Caribbean began in the middle of the nineteenth century, and during the first half of the twentieth century most of the species were described. The number of ecological studies increased in the 1970s that continues until today, mostly focused on Diadema antillarum. Based on an extensive review of published records, the Caribbean echinoderm fauna is composed of 433 species, 237 genera, 80 families, 29 orders in five classes, with four endemic species. The richest class is Ophiuroidea with 148 species followed by the class Asteroidea with 116 species. Mexico and Colombia are the richest countries with 182 and 180 species respectively, while Costa Rica and Guatemala are the less diverse with fewer than 50 species. In general terms, the Caribbean is very homogeneous in species composition; however, Colombia and Mexico are the countries more dissimilar in composition with respect to the rest of countries. This semi-enclosed sea represents $6.5 \%$ of the total diversity of the phylum worldwide, and is the second most diverse area in tropical America, after Gulf of Mexico. Six species of echinoderms are extracted for commercial use, mostly in Panama, Nicaragua, Colombia,
\end{abstract}

J. J. Alvarado $(\square)$

Centro de Investigación en Ciencias del Mar y Limnología

(CIMAR), Universidad de Costa Rica (UCR),

San Pedro, 11501-2060 San José, Costa Rica

e-mail: juanalva76@yahoo.com

\section{J. J. Alvarado}

Posgrado en Ciencias Marinas y Costeras (CIMACO),

Universidad de Baja California Sur (UABCS),

La Paz, México
Venezuela and Cuba. However, extraction for the souvenir trade, without any regulation and control, is one of the major threats for some animals - especially the sea star Oreaster reticulatus. Research priorities for this group in the Caribbean include exploration of the deep sea, the Central American region and the Lesser Antilles. Moreover, because of its rich biodiversity, research and conservation efforts have to be directed towards its preservation, avoiding illegal extraction, enforcing controls, and improving coastal zone management.

Keywords Echinoderms · Diversity · Richness · Similarity · Historic account $\cdot$ Caribbean

\section{Introduction}

The Caribbean Sea is a large sea, closed off to the west and to the south by the Americas, and partly screened to the north and to the east by the island chains of the Greater and Lesser Antilles (Spalding 2004). The region extends over about $2,754,000 \mathrm{~km}^{2}$ in which $36-40$ politically independent countries and territories can be found (Miloslavich and Klein 2005). Two large currents sweep towards this region from the Atlantic, the North Equatorial Current and Guyana current. A portion of their flow runs between the islands and into the Caribbean Sea, forming a generally westward flow known as the Caribbean current. The rest of the current is deflected to the northwest, fusing with the Gulf Stream (Spalding 2004).

The Caribbean is considered a unique biogeographic region. It is among the top five hotspots in the world for marine and terrestrial biodiversity, and it has many endemic species (Rivera-Monroy et al. 2004). Its complex geological history, begining 130 million years ago (Ma) and involving 
emergence of the Isthmus of Panama in the Pliocene (around 3.0-2.8 Ma), had major effects on the marine biodiversity. The separation of the tropical American ocean into two different realms produced isolation and environmental change that resulted in increased evolutionary divergence and radiation of species in extensive coral reefs, mangroves, seagrass beds, deep-shelf ecosystems and partially isolated deep basins and trenches (Collins 1996).

The echinoderm research on the Caribbean began in the middle of the nineteenth century with dredging explorations in Florida and Cuba (Agassiz 1869; Lyman 1869). The first half of the twentieth century increased the number of species described with collections from Puerto Rico (Clark 1901), the Lesser Antilles (Engel 1933), Jamaica (Fointaine 1953a, b, c), and the publication of monographs on groups such as Holothuroidea (Deichmann 1926, 1930, 1940, 1963). During the second half of the twentieth century research increased the number of local records in Cuba (Suárez 1974), Belize (Devaney 1974; Kier 1975; Hotchkiss 1982; Macurda 1982; Hendler and Pawson 2000), Panama (Chesher 1972), Venezuela (Zoppi de Roa 1967; Rodríguez 1969, 1973; Martínez and Mago 1975; Martínez 1987, 1989), Jamaica (Meyer 1973), Honduras (Lessios 1998; Hasbún and Lawrence 2002). During this period information on groups such as Asteroidea (Downey 1973; Clark and Downey 1992) and Crinoidea (Meyer et al. 1978) was augmented. This increase in research is partially a consequence of the work in Panama conducted by the Smithsonian Tropical Research Institution and research in other parts of the Caribbean by the Smithsonian Institution in Washington DC.

During the 1970s, there was an increase in ecological studies that continues to our times, mostly focused on Diadema antillarum (Ogden et al. 1973; Sammarco 1980, 1982a, b; Lessios et al. 1984; Lessios 2005; Weil et al. 2005; Mumby et al. 2006; Steiner and Williams 2006; among others). However, one of the most important works was the compilation by Hendler et al. (1995), containing keys, pictures and a detailed description of 144 species. It also contained general comments on their habitat, distribution and biology. In addition to taxonomy, research in the region has focused on topics such as bioerosion (Scoffin et al. 1980; Bak et al. 1984; Griffin et al. 2003; BrownSaracino et al. 2007), biodiversity (Price et al. 1999), reproduction (Lessios 1981a; Guzmán and Guevara 2002a, b; Guzmán et al. 2003; Montealegre-Quijano and GómezGaspar 2005), aquaculture (Buitrago and Lodeiros-Seijo 2005; Gómez and Gómez 2005), evolution (Lessios 1981b; Lessios et al. 2001; Lessios et al. 2003; Zigler and Lessios 2004), and competition (Parker and Shulman 1986). The majority of this research was focused on echinods. The Caribbean region likely ranks among the top tropical regions for echinoderms research.
More recently, more research has being carried out, in Colombia (Benavides-Serrato and Borrero-Pérez 2000; Benavidez-Serrato et al. 2005; Borrero-Pérez et al. 2002a, b, 2008), Cuba (Abreu-Pérez et al. 2005; Del Valle-García et al. 2005, 2008), Mexico (Laguarda-Figueras et al. 2005), Hispaniola Island (Herrera-Moreno and Betancourt 2004) and Puerto Rico (Benavides-Serrato 2006). In the past decade scientist from the Instituto de Investigaciones Marinas y Costeras (INVEMAR) have publish most on echinoderm diversity in both shallow and deep water habitats.

The aim of this review is to present an updated list of the echinoderms in the Caribbean region based on information from the literature and museum collections. A list of species is presented indicating their presence in each country, the similarities in species composition, and the possible causes of those patterns of distribution.

\section{Material and methods}

I reviewed the echinoderm species composition of the Caribbean coast from the Yucatán Peninsula in Mexico (Quintana Roo State) to Venezuela, including the arc of the Caribbean islands from Cuba to Trinidad \& Tobago (Fig. 1). The ecoregions covered by this review included the Eastern Caribbean, Greater Antilles, Southern Caribbean, Southwestern Caribbean and Western Caribbean of the Tropical Northwestern Atlantic Province (Spalding et al. 2007). Existing published echinoderm studies were reviewed (Zoppi de Roa 1967; Chesher 1968, 1970; Flores and Martínez 1970; Serafy 1970; Meyer 1973; Devaney 1974; Martínez and Mago 1975; Meyer and Macurda 1976; Meyer et al. 1978; Caycedo 1978, 1979; Alvarez-Larrauri 1981; Hotchkiss 1982; Macurda 1982; Miller and Pawson 1984; Martínez 1987; Hendler 1988, 1995; Clark and Downey 1992; Hendler et al. 1995; Schoppe 1996; Lessios 1998; Benavides-Serrato and Borrero-Pérez 2000; Hendler and Pawson 2000; Pawson et al. 2001; Borrero-Pérez et al. 2002a, b; Gómez-Gaspar 2002; Gonzalez et al. 2002; Hasbún and Lawrence 2002; Fonseca and Arrivillaga 2003; Herrera-Moreno and Betancourt 2004; Abreu-Pérez et al. 2005; Benavidez-Serrato et al. 2005; Del Valle-García et al. 2005; Laguarda-Figueras et al. 2005; Benavides-Serrato 2006; Alvarado et al. 2008; Borrero-Pérez et al. 2008; Francisco and Pauls 2008), and extracted information from the Geology Collection of the California Academy of Sciences, San Francisco (http://www.calacademy.org/research/izg/ iz_coll_db/index.asp). The taxa were validated with the Integrated Taxonomic Information System (http://www.itis. gov/), and the Ophiuroidea (Stöhr and O'Hara 2007) and Asteroidea databases (Mah 2009). For the taxonomic list, the criteria used in Alvarado et al. (2008) were applied. 


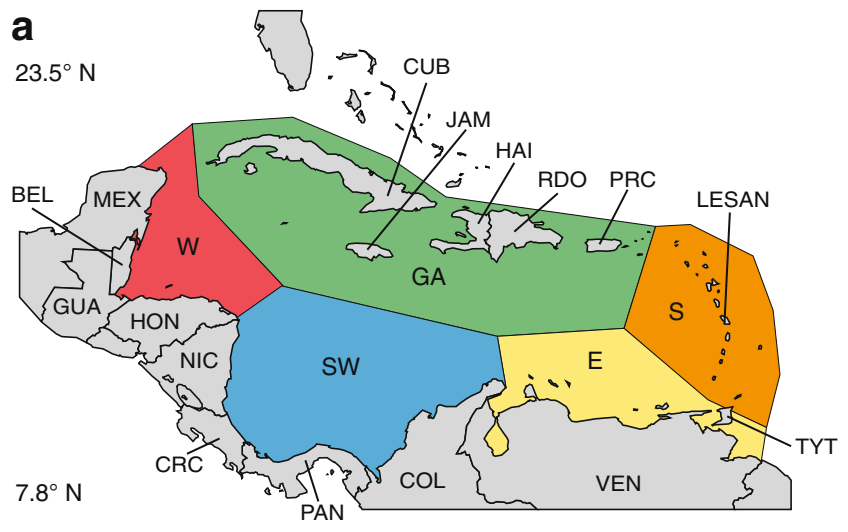

$86.1^{\circ} \mathrm{N}$

$62.6^{\circ} \mathrm{W}$

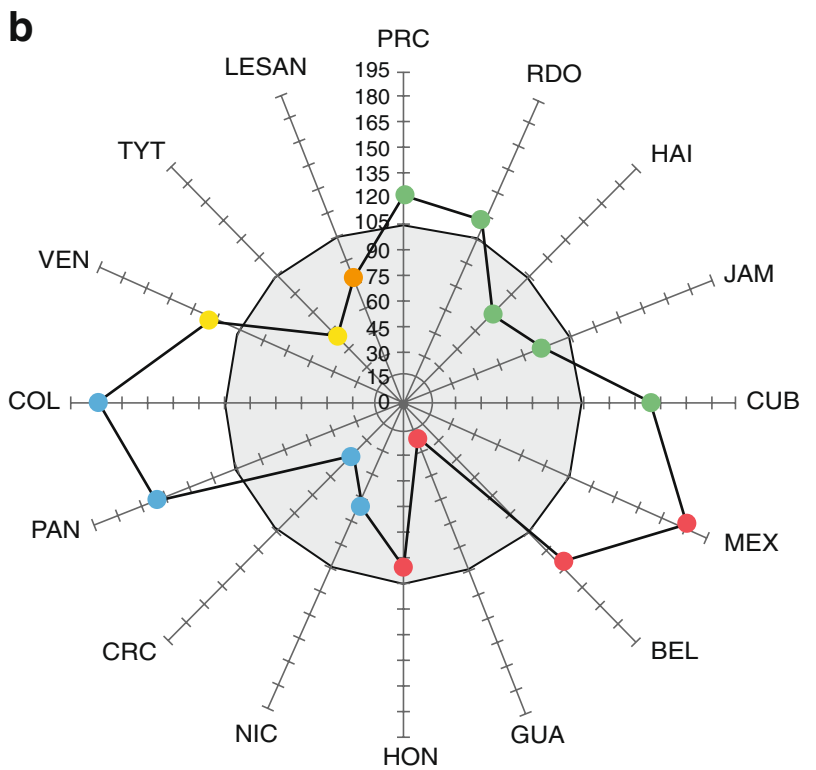

Fig. 1 a Caribbean Sea countries and ecoregions. b Radial diagram of the number of species of echinoderms (axes) per country on the Caribbean. Gray circle countries with under the average number of species. Ecoregions: $W$ Western Caribbean (blue dots), SW Southwestern Caribbean (green dots), GA Greater Antilles (red dots), E Eastern Caribbean (yellow dots), $S$ Southern Caribbean (orange dots). PRC Puerto Rico, RDO Dominican Republic, HAI Haiti, JAM Jamaica, $C U B$ Cuba, MEX Mexico, BEL Belize, GUA Guatemala, $H O N$ Honduras, NIC Nicaragua, CRC Costa Rica, PAN Panama, COL Colombia, VEN Venezuela, TYT Trinidad \& Tobago, LESAN Lesser Antillers

I used the year of publication of the description of each currently valid species to examine patterns in the rate of species descriptions over time, and to construct species accumulation curves for the entire described fauna. I followed the criteria from Zapata and Robertson (2007), to predict the total fauna size using the logistic model in the PAST computer program.

Composition similarities for each country were estimated by a presence/absence matrix per class and for the complete phylum. With those matrixes, I applied a Euclidean distance similarity matrix and I compared the diversity of echinoderms with a cluster tree and non-metric multidimensional scaling (nMDS). I estimated the average taxonomic distinctness $\left(\Delta^{+}\right)$and its variation $\left(\Lambda^{+}\right)$(Clarke and Warwick 2001). This index evaluated the taxonomic distance between each pair of individuals, defined by a Linnaean classification tree, and could be used with a presence/absence matrix without taking into consideration the sampling methodology used. This index is considered as one of the most precise indicators in a strict biodiversity sense (Clarke and Warwick 2001). It was used on five taxonomic levels: species, genus, family, order and class, with their respective weights $\omega=20$ (species in the same genera), 40 (same family but different genus), 60 (same order but different family), 80 (same class but different order) and 100 (different class). The statistical analysis was performed with the PRIMER 6.0 software.

\section{Results}

The list of echinoderms of the Caribbean includes 433 species, 237 genera, 80 families, 29 orders and five classes (Table 1), with four endemic species. The richest class was Ophiuroidea with 148 species, followed by the class Asteroidea with 116 species, then Echinoidea and Holothuroidea with 76 and 63 species respectively, and finally the class Crinoidea with 30 species (Table 2). Mexico and Colombia are the richest countries with 182 and 180 species respectively, followed by Panama with 155 species and Cuba with 145 species (Table 3). Eight countries possess between 100 and 182 species, six between 50 and 99 species, and only two countries possess less than 50 species, Costa Rica and Guatemala with 44 and 23 species respectively. There is an average of 105 species per country (Table 3). The average number of species per kilometer (spp. $/ \mathrm{km}$ ) of coastline is $0.13 \pm 0.07 \mathrm{spp} . / \mathrm{km}$, Belize being the richest country with $0.26 \mathrm{spp} . / \mathrm{km}$, and Cuba, Haiti, and Venezuela the poorest with $0.04 \mathrm{spp} . / \mathrm{km}$. The average number of spp. $/ \mathrm{km}^{2}$ of Economic Exclusive Zone (EEZ) is $0.0022 \mathrm{spp} . / \mathrm{km}^{2}$ of EEZ. Based on this metric, Guatemala is the richest country with $0.0140 \mathrm{spp} . / \mathrm{km}^{2}$ of EEZ, followed by Honduras (0.0052 spp. $\left./ \mathrm{km}^{2}\right)$, and Venezuela and Jamaica are the poorest with $0.0003 \mathrm{spp} . / \mathrm{km}^{2}$ of EEZ (Table 3).

Among the Class Crinoidea, the Dominican Republic (RDO) is the richest country with 17 species, followed by Panama and Jamaica with 15 each (Table 3), while Trinidad $\&$ Tobago and Guatemala are the poorest with three and two respectively. Davidaster discoidea and D. rubiginosa were reported from 12 countries, while eight species were reported only from one country. The genera Davidaster and Democrinus were the most diverse with three species each. 

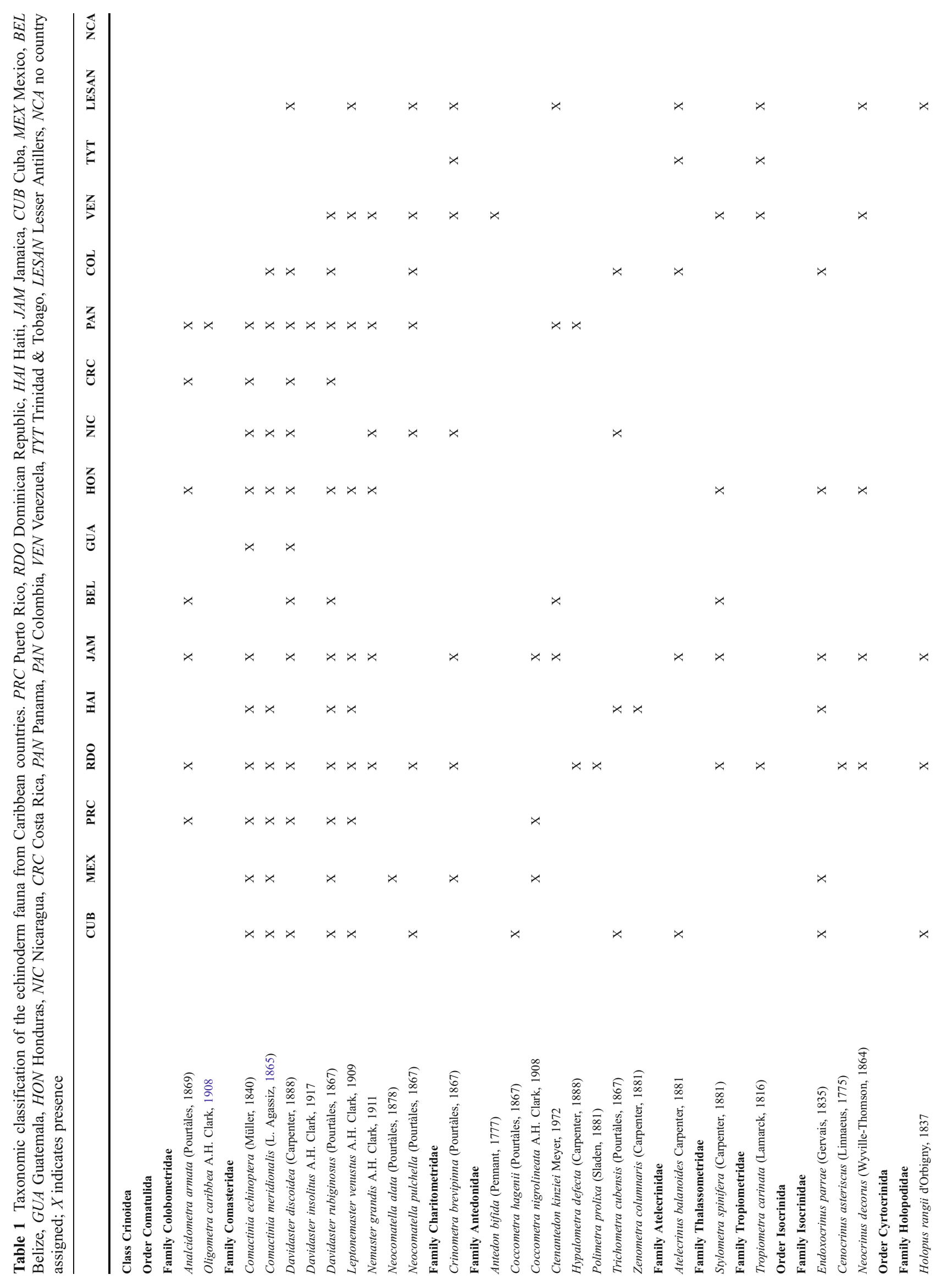

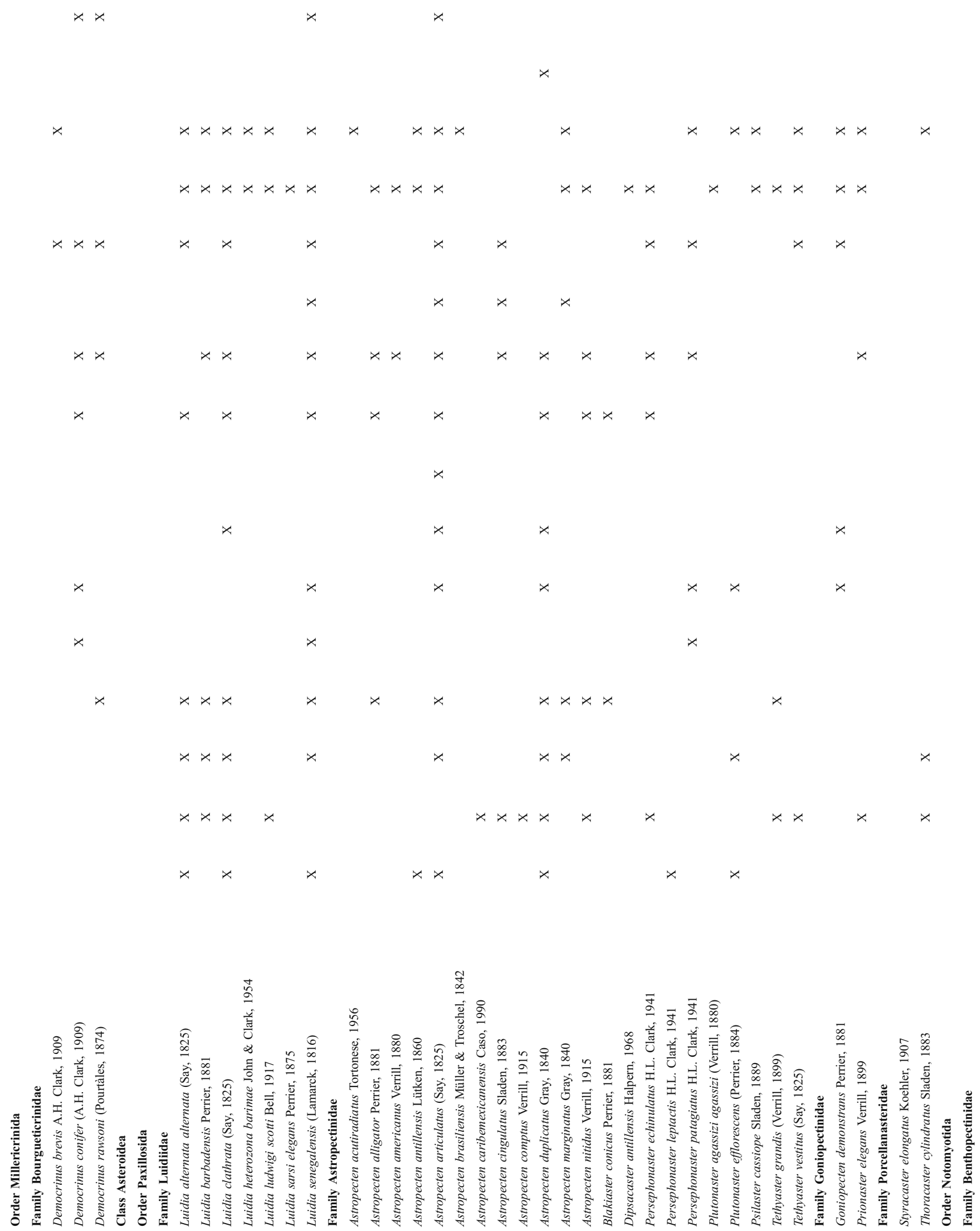


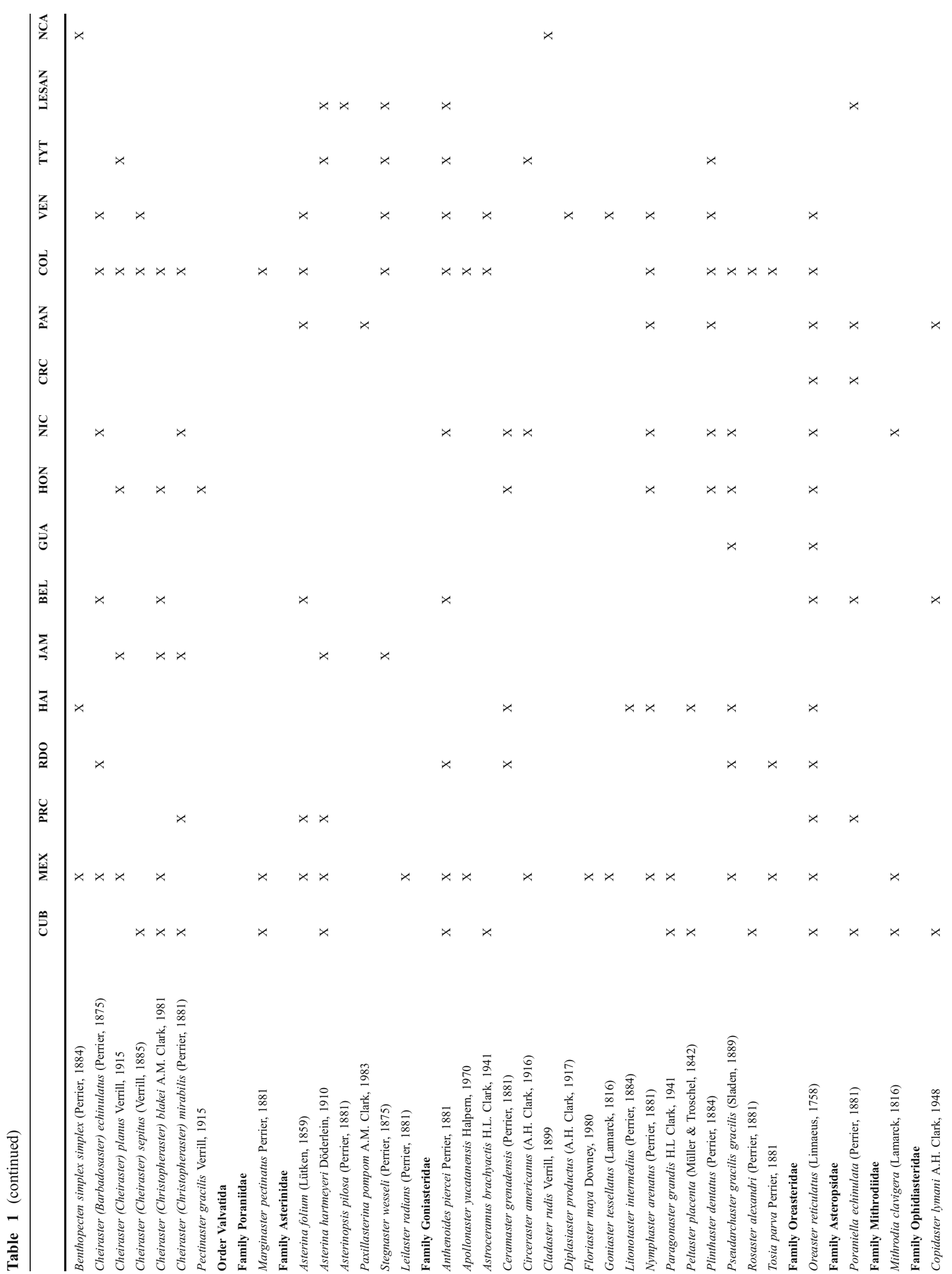



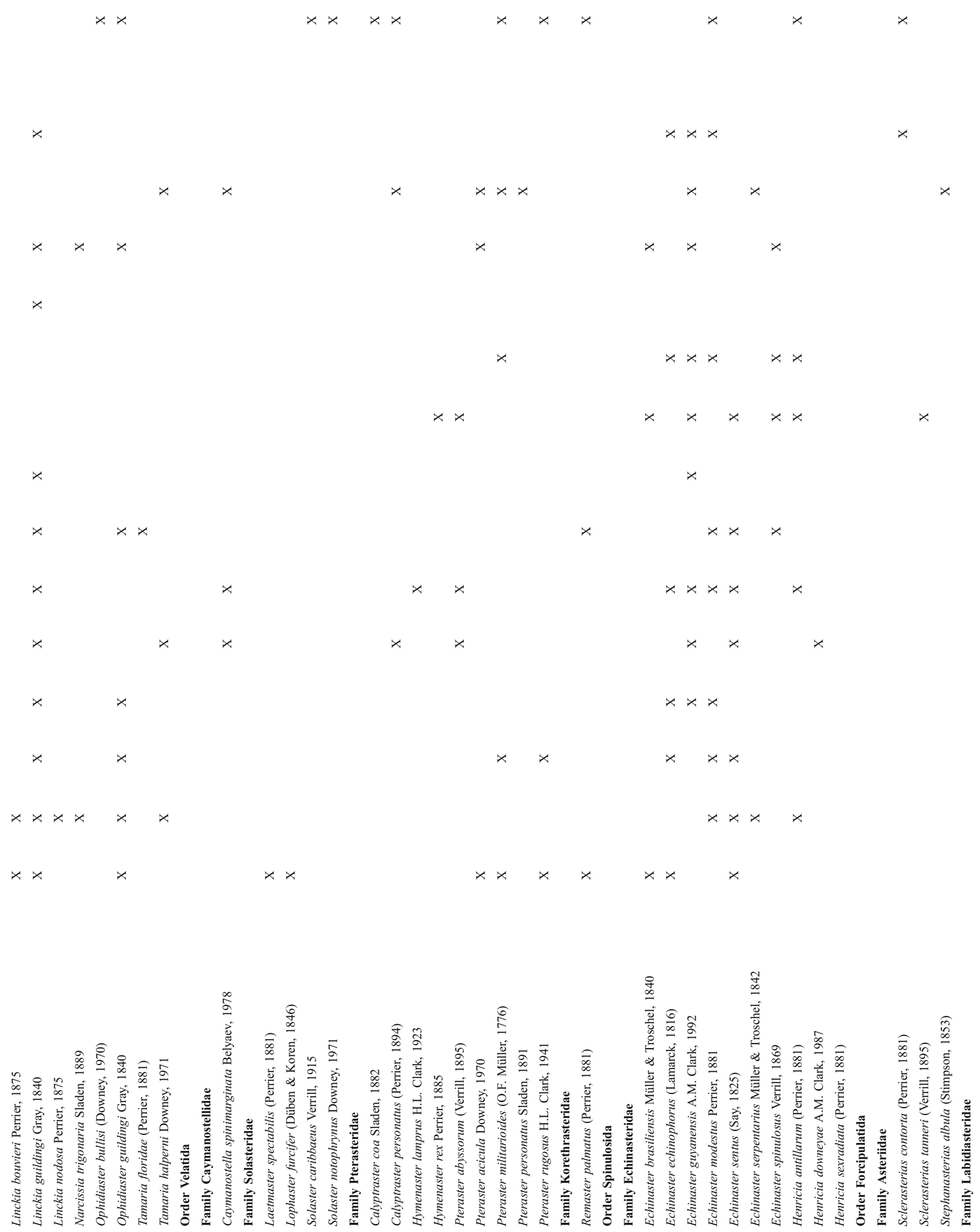


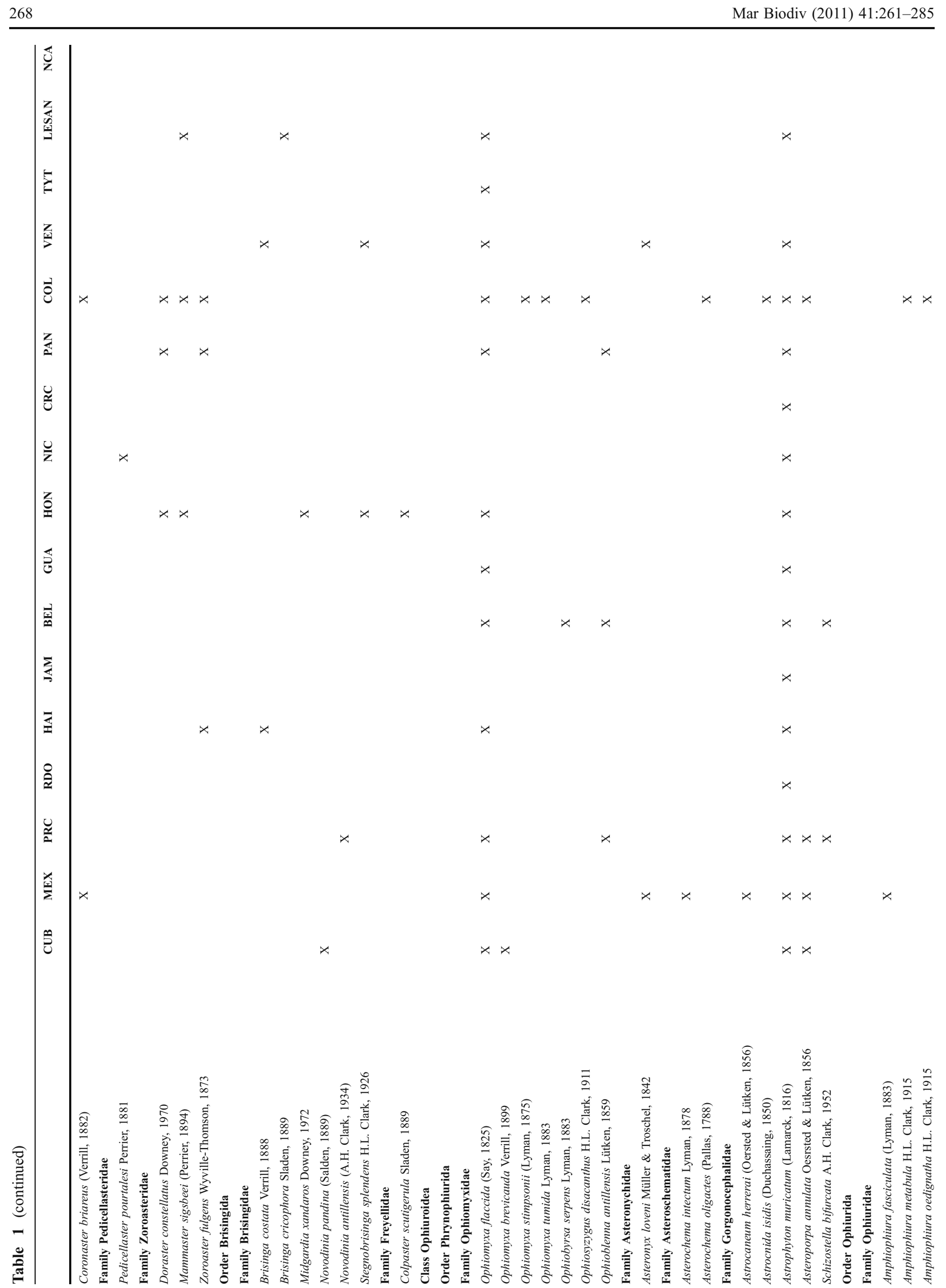

望 Springer 


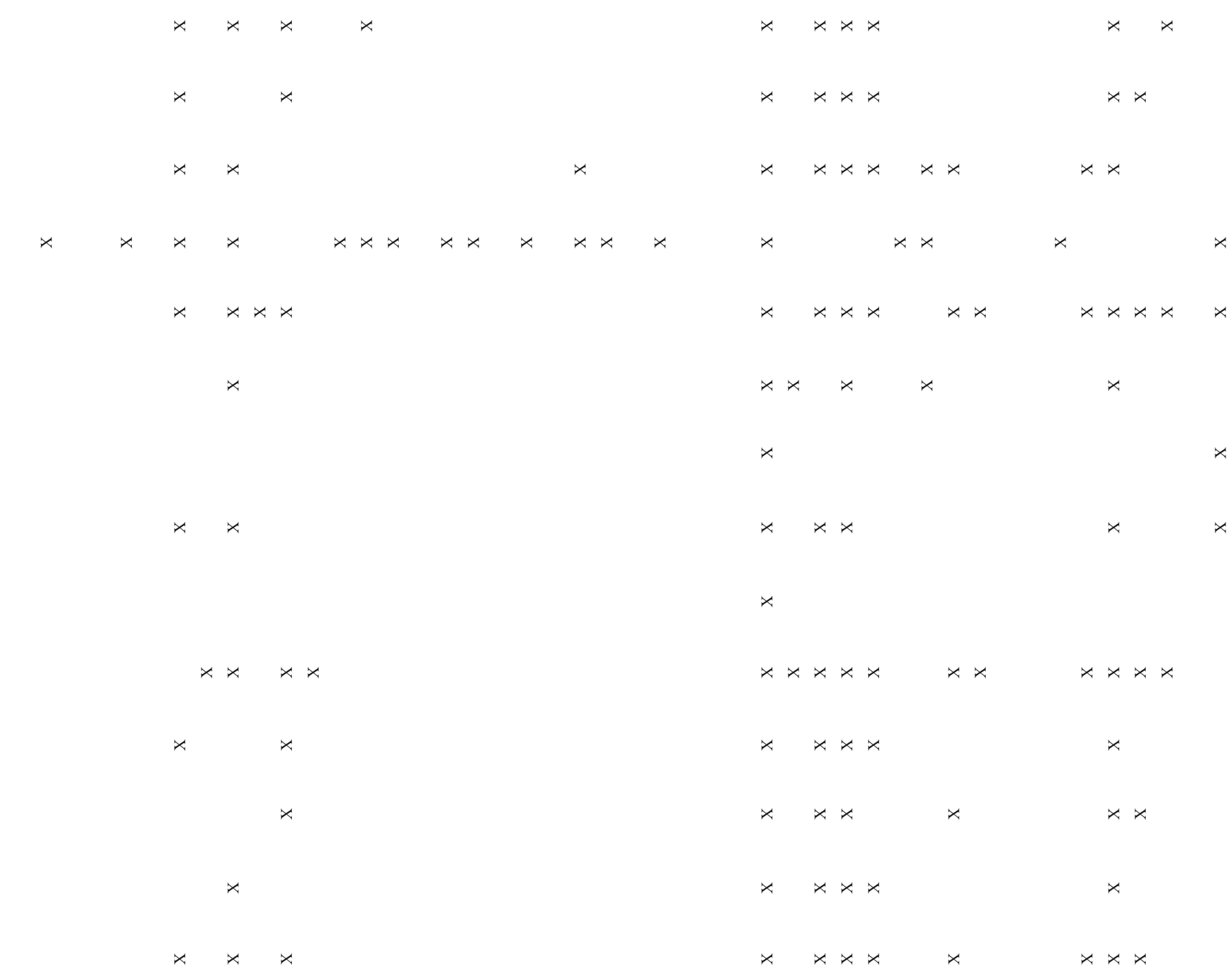

$x+x \times \sin x \times x+4$

$x x x x x$

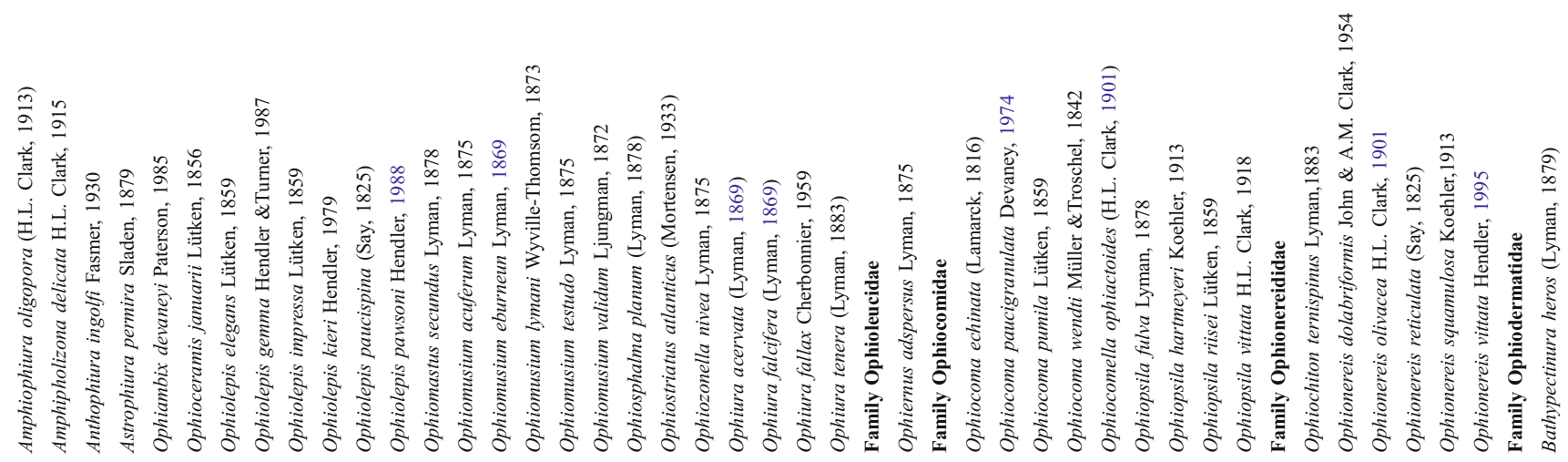




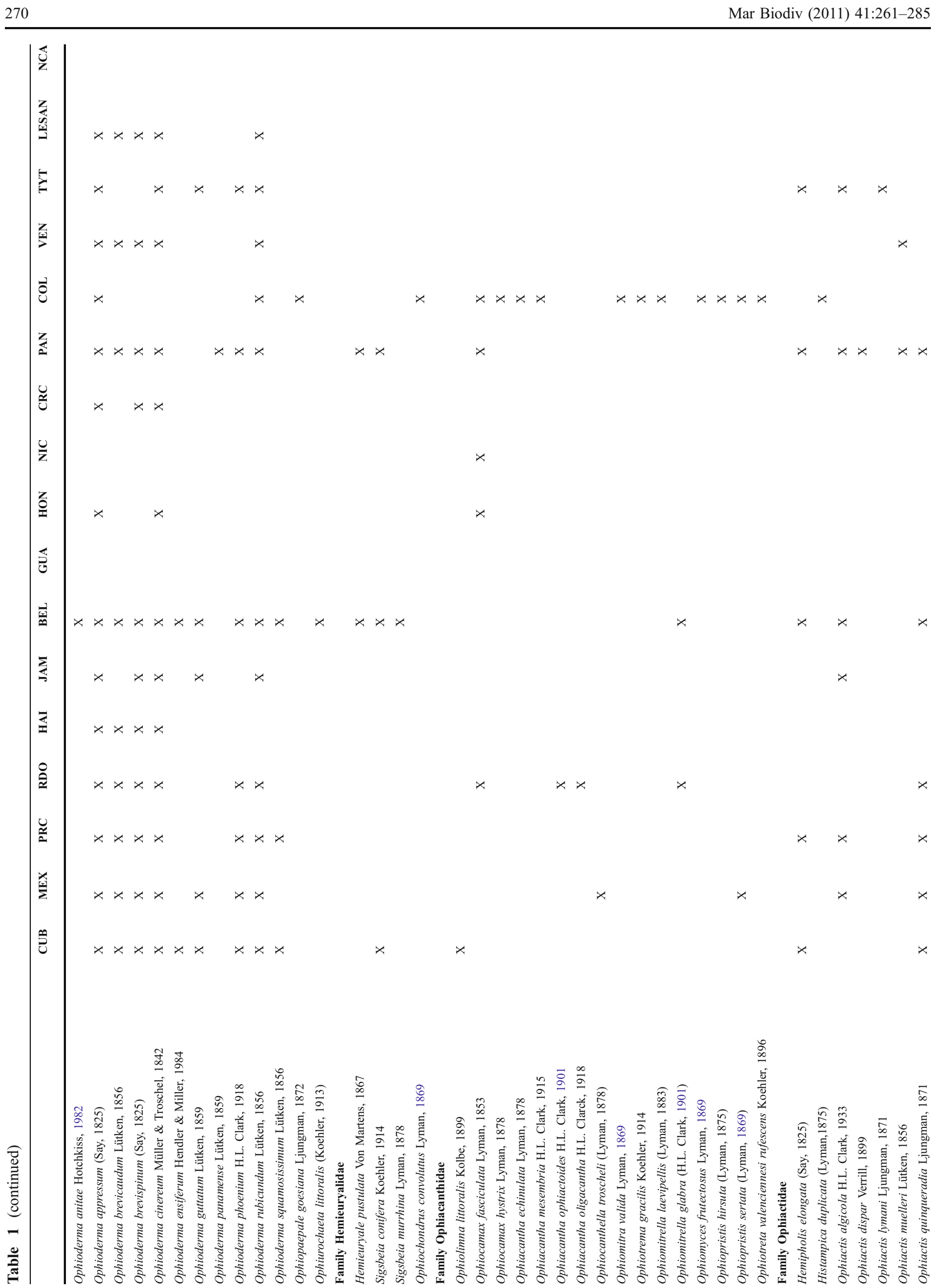

Springer 

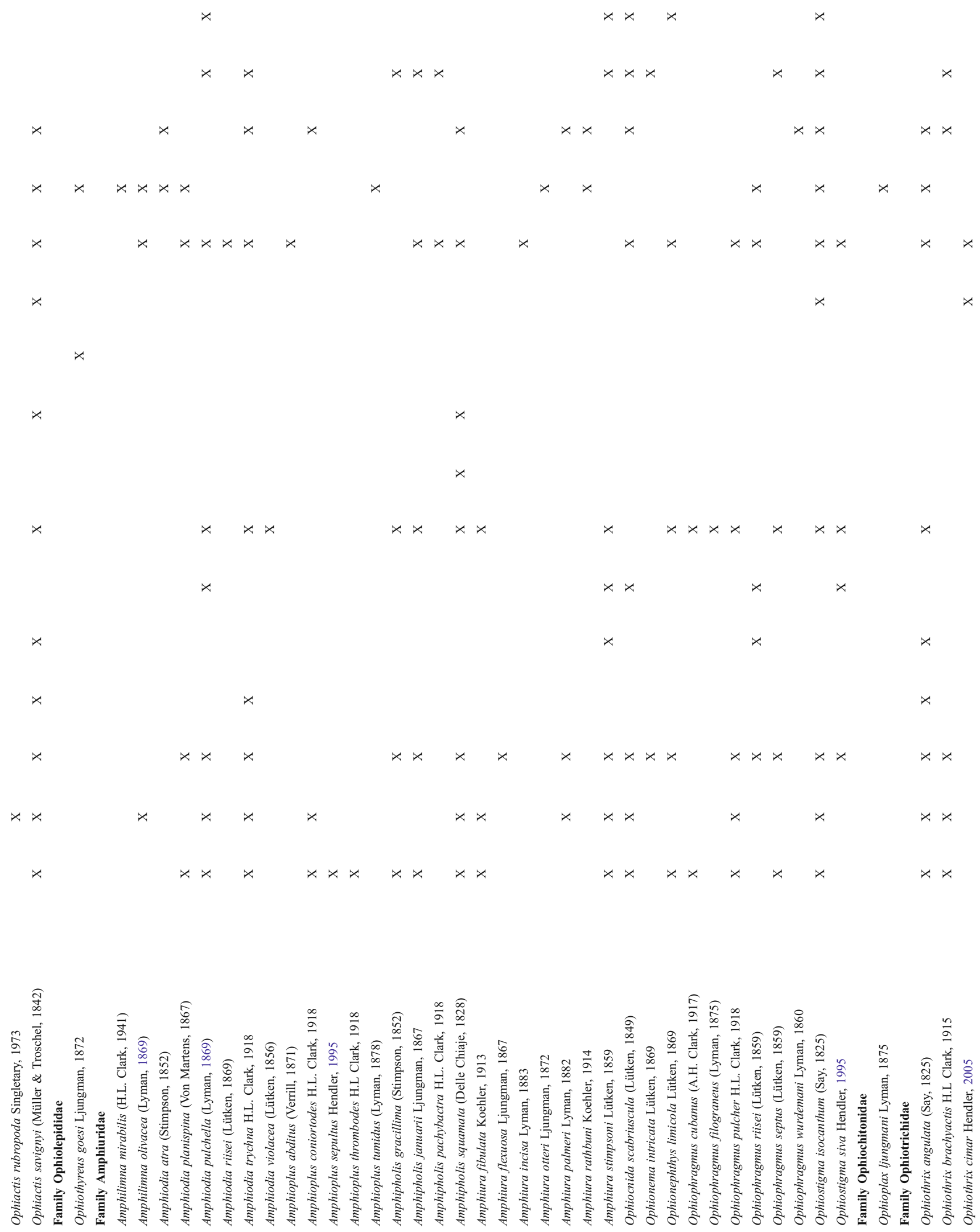


$$
\text { L }
$$



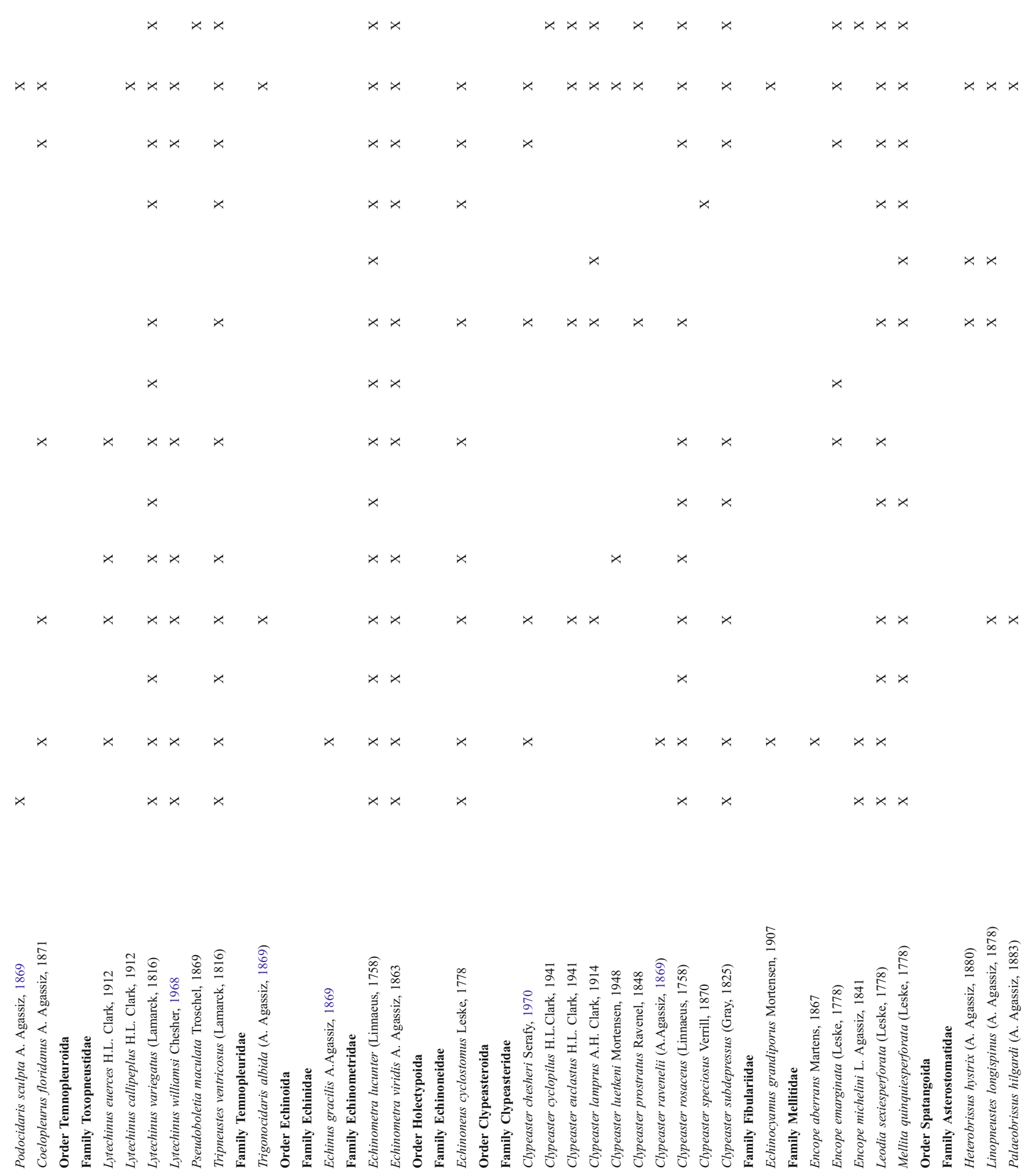


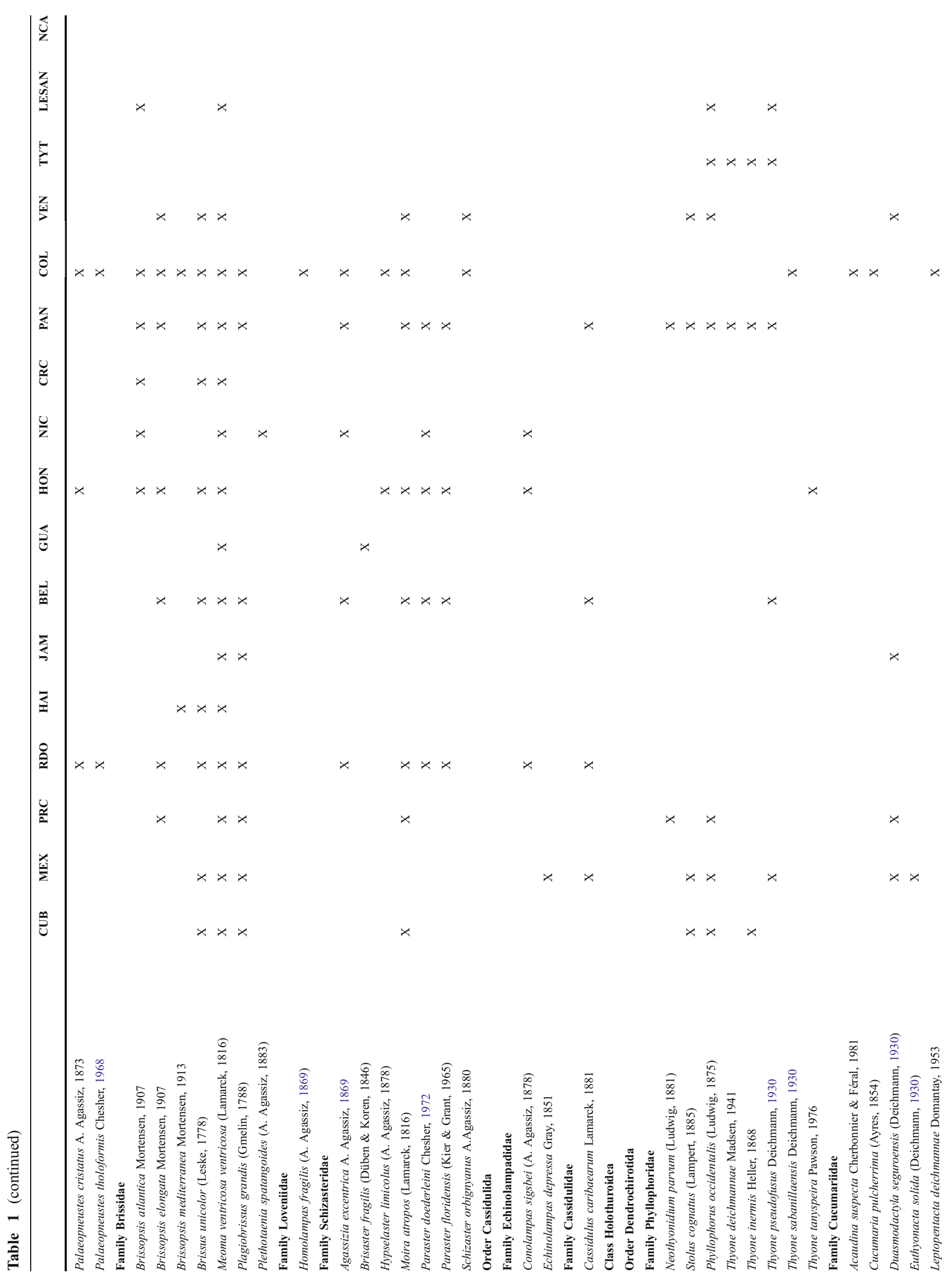




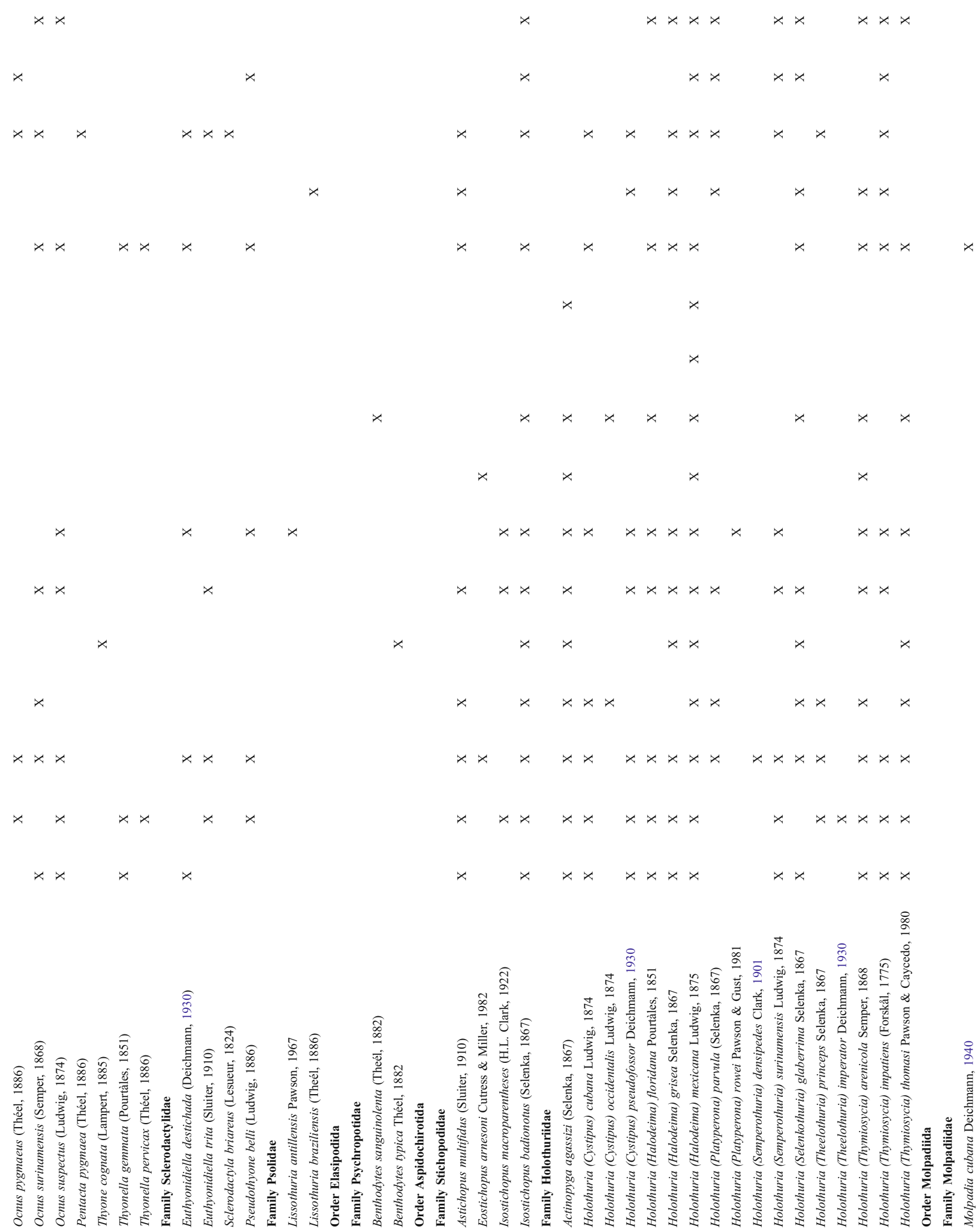




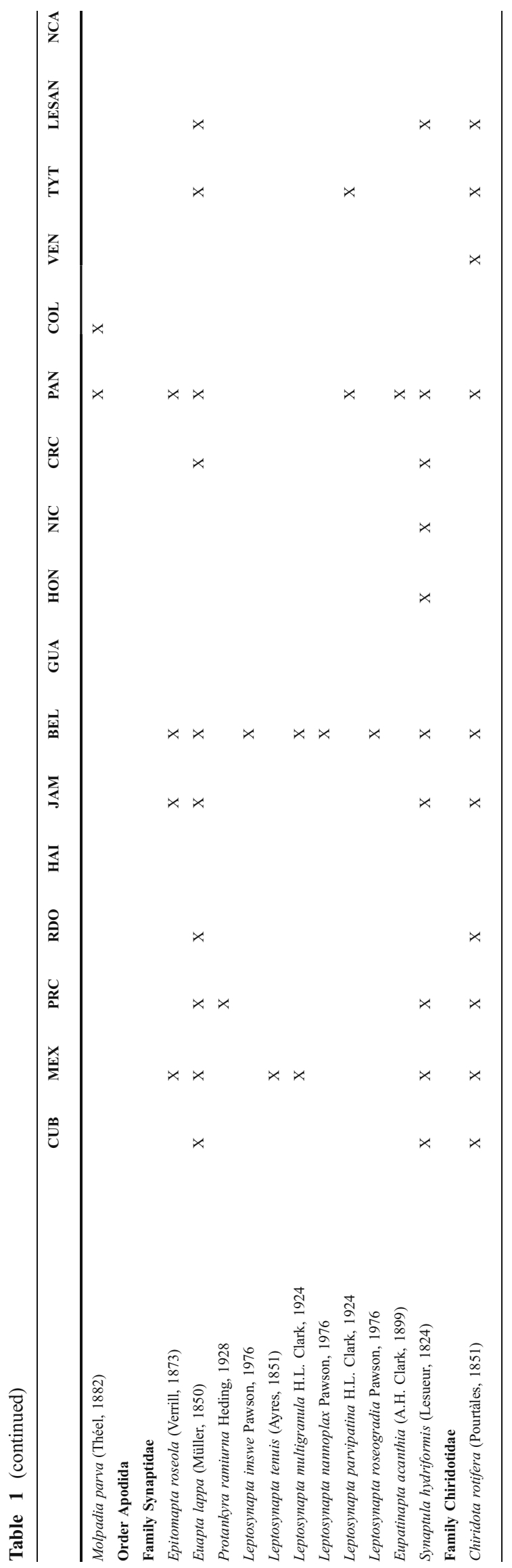

Colombia was the richest country for the class Asteroidea with 51 species followed by Mexico with 44 species. For this class, Astropecten is the most diverse genus with 12 species. Astropecten articulatus and Oreaster reticulatus are reported from 13 countries, and 38 species are reported for only one country. Laetmaster spectabilis is endemic to Cuba. Four species were reported for international waters: Styracaster elongatus, Benthopecten simplex simplex, Cladaster rudis and Henricia sexradiata.

With respect to the Class Ophiuroidea, Mexico, Colombia, Belize and Panama exhibited the highest species richness with $63,62,58$ and 56 species respectively, while Nicaragua and Guatemala were the least diverse with six and four species each (Table 3). Ophioderma was the most diverse genus with 11 species. Ophiocoma echinata was the only species reported in the entire region (16 countries or territories), while Astrophyton muricatum was reported from 15 countries and Ophioderma appressum from 14. For this class 71 species were reported from only one country, and the species Ophiothrix synoecina is endemic to Colombia, and O. stri and O. cimar are endemic to Costa Rica and Panama.

With respect to Echinoidea, Colombia was the richest country with 47 species, followed by the Dominican Republic with 41 (Table 3). Clypeaster was the most diverse genus with ten species; Meoma ventricosa ventricosa was reported in 15 countries and Echinometra lucunter and Eucidaris tribuloides in 14. In this class, 18 species were reported from only one country.

Mexico was the richest country for the Holothuroidea with 32 species, followed by Panama and Puerto Rico with 30 species each, while Guatemala, Costa Rica, and Nicaragua were the least diverse (Table 3). Holothuria was the most diverse genus with 16 species; Holothuria (Halodeima) mexicana was reported for 15 countries and Isostichopus badionotus for 12. Within this class, 23 species were reported for only one country.

Initially, the publication of echinoderm species descriptions in the Caribbean Sea was slow (Fig. 2a, b), with an average of 0.47 species described per year between 1740 and 1840. Between 1840 and 1920, there was a substantial increase (3.83 species described per year), followed by a slower rate between 1920 and the present, with 0.91 species described per year. Taking the entire period of 1740 to 2010, there were on average 1.61 species described per year. According to the logistic model (Fig. 2b), the curve will be reaching an asymptote in the next 50 years, with seven probable undescribed species to be named.

Colombia and Mexico, the most diverse countries, are the most dissimilar in comparison relative to the rest of the region (Figs. 3, 4, gray areas). The difference is primarily due to the composition of Asteroidea (Figs. 3c, 4c), Ophiuroidea (Figs. 3d, 4d) and Echinoidea (Figs. 3e, 4e), 
Table 2 Species, genera, families and orders of Caribbean echinoderms

\begin{tabular}{lllll}
\hline Class & Order & Family & Genus & Species \\
\hline Crinoidea & 4 & 10 & 23 & 30 \\
Asteroidea & 7 & 23 & 68 & 116 \\
Ophiuroidea & 2 & 16 & 63 & 148 \\
Echinoidea & 11 & 21 & 53 & 76 \\
Holothuroidea & 5 & 10 & 30 & 63 \\
Total & 29 & 80 & 237 & 433 \\
\hline
\end{tabular}

and to the influences from other regions like the Gulf of Mexico, Florida and Brazil. In general terms, the Caribbean is very homogenous in species composition between countries (Figs. 3, 4).

The taxonomic distinctness index $\left(\Delta^{+}\right)$indicated that most of the countries are inside the $95 \%$ confidence limit of composition; Panama, Cuba, Mexico and Colombia (Fig. 5) being closer to the average of distinctness. Guatemala possesses few species (23 spp.) but exhibits a high value of distinctness $\left(\Delta^{+}\right)$, because those species represent many different groups with few representatives in each one, making the taxonomic distance greater. In Guatemala, each class is represented more or less equally by two to eight species, with very low variation (Fig. 5b). On the other hand, Trinidad \& Tobago, which also has few species (55 spp.), has a lower distinctness value $\left(\Delta^{+}\right)$, because the species are unequally represented. The 55 species are dominated by two groups, Ophiuroidea (29 spp.) and Holothuroidea (15 spp.), while the other classes possess fewer species, so the average taxonomic distance is lower (Fig. 5a), with a greater variation (Fig. 5b).

\section{Discussion}

The Caribbean Sea is a marine province rich in echinoderm species. It has 433 species, representing $6.5 \%$ of the total diversity of the phylum, according to numbers presented by Pawson (2007). This region possesses almost $10 \%$ of the world's Ophiuroidea, and between 4 and $6 \%$ of the other classes. The Caribbean is second in the tropical Americas with respect to species numbers, after the Gulf of Mexico (522 species; Pawson et al. 2009). The Caribbean ranks above other regions like Brazil (329 species; Hadel et al. 1999), the Pacific of Central America (287; Alvarado et al. 2010), Baja California and the Gulf of California (231 species; SolísMarín et al. 2005; Honey-Escandón et al. 2008), and the Galapagos Archipelago (198 species; Maluf 1991).

The Caribbean, with an apparent well-known echinoderm fauna (Fig. 2b), is highly homogeneous in composition, due mostly to the current patterns and the semi-closed nature of the region (Spalding 2004). This sea has been recognized as one of the most important coral reef biogeographic provinces (Spalding et al. 2001), with many

Table 3 Number of echinoderm species per class in each country. Coastline information taken from the The world fact book (https://www.cia.gov/ library/publications/the-world-factbook/geos) and Economic Exclusive Zone (EEZ) information was taken from www.seaaroundus.org/eez/eez.aspx

\begin{tabular}{|c|c|c|c|c|c|c|c|c|c|c|}
\hline Country & Crinoidea & Asteroidea & Ophuiroidea & Echinoidea & Holothuroidea & Total & $\begin{array}{l}\text { Coastline } \\
(\mathrm{km})\end{array}$ & $\begin{array}{l}\text { No. spp. } / \mathrm{km} \\
\text { of coastline }\end{array}$ & $\begin{array}{l}\mathrm{EEZ} \\
\left(\mathrm{km}^{2}\right)\end{array}$ & ssp. $/ \mathrm{km}^{2} \mathrm{EEZ}$ \\
\hline Mexico $^{a}$ & 7 & 44 & 63 & 36 & 32 & 182 & 905 & 0.20 & 88,874 & 0.0020 \\
\hline Colombia & 7 & 51 & 62 & 47 & 13 & 180 & 1,760 & 0.10 & 472,891 & 0.0004 \\
\hline Panama & 15 & 25 & 56 & 29 & 30 & 155 & 1,295 & 0.12 & 143,442 & 0.0011 \\
\hline Cuba & 11 & 35 & 55 & 21 & 23 & 145 & 3,755 & 0.04 & 350,751 & 0.0004 \\
\hline Belize & 5 & 18 & 58 & 27 & 26 & 134 & 516 & 0.26 & 35,351 & 0.0038 \\
\hline Venezuela & 10 & 36 & 34 & 24 & 20 & 124 & 2,800 & 0.04 & 470,666 & 0.0003 \\
\hline Puerto Rico & 7 & 22 & 48 & 14 & 30 & 121 & 501 & 0.24 & 205,529 & 0.0006 \\
\hline Dominican Republic & 17 & 22 & 23 & 41 & 14 & 117 & 1,280 & 0.09 & 255,898 & 0.0005 \\
\hline Honduras & 11 & 30 & 14 & 29 & 11 & 95 & 644 & 0.15 & 18,151 & 0.0052 \\
\hline Jamaica & 15 & 20 & 20 & 10 & 21 & 86 & 1,022 & 0.08 & 258,137 & 0.0003 \\
\hline Lesser Antilles & 11 & 21 & 23 & 7 & 17 & 79 & - & - & - & - \\
\hline Haiti & 8 & 19 & 19 & 19 & 8 & 73 & 1,771 & 0.04 & 126,760 & 0.0006 \\
\hline Nicaragua & 9 & 29 & 6 & 19 & 2 & 65 & 503 & 0.13 & 87,930 & 0.0007 \\
\hline Trinidad \& Tobago & 3 & 7 & 29 & 1 & 15 & 55 & 362 & 0.15 & 74,199 & 0.0007 \\
\hline Costa Rica & 4 & 7 & 16 & 13 & 4 & 44 & 212 & 0.21 & 25,090 & 0.0018 \\
\hline Guatemala & 2 & 5 & 4 & 8 & 4 & 23 & 150 & 0.15 & 1,642 & 0.0140 \\
\hline No country assigned & 0 & 4 & 0 & 0 & 0 & 4 & - & - & - & - \\
\hline
\end{tabular}

${ }^{\text {a }}$ Shore line and economic exclusive zone are from Quintana Roo State 
Fig. 2 a Number of new species of echinoderms from the Caribbean described by decade. b Accumulation curves of species descriptions for the total (gray line) and with the fitted logistic model (black line)

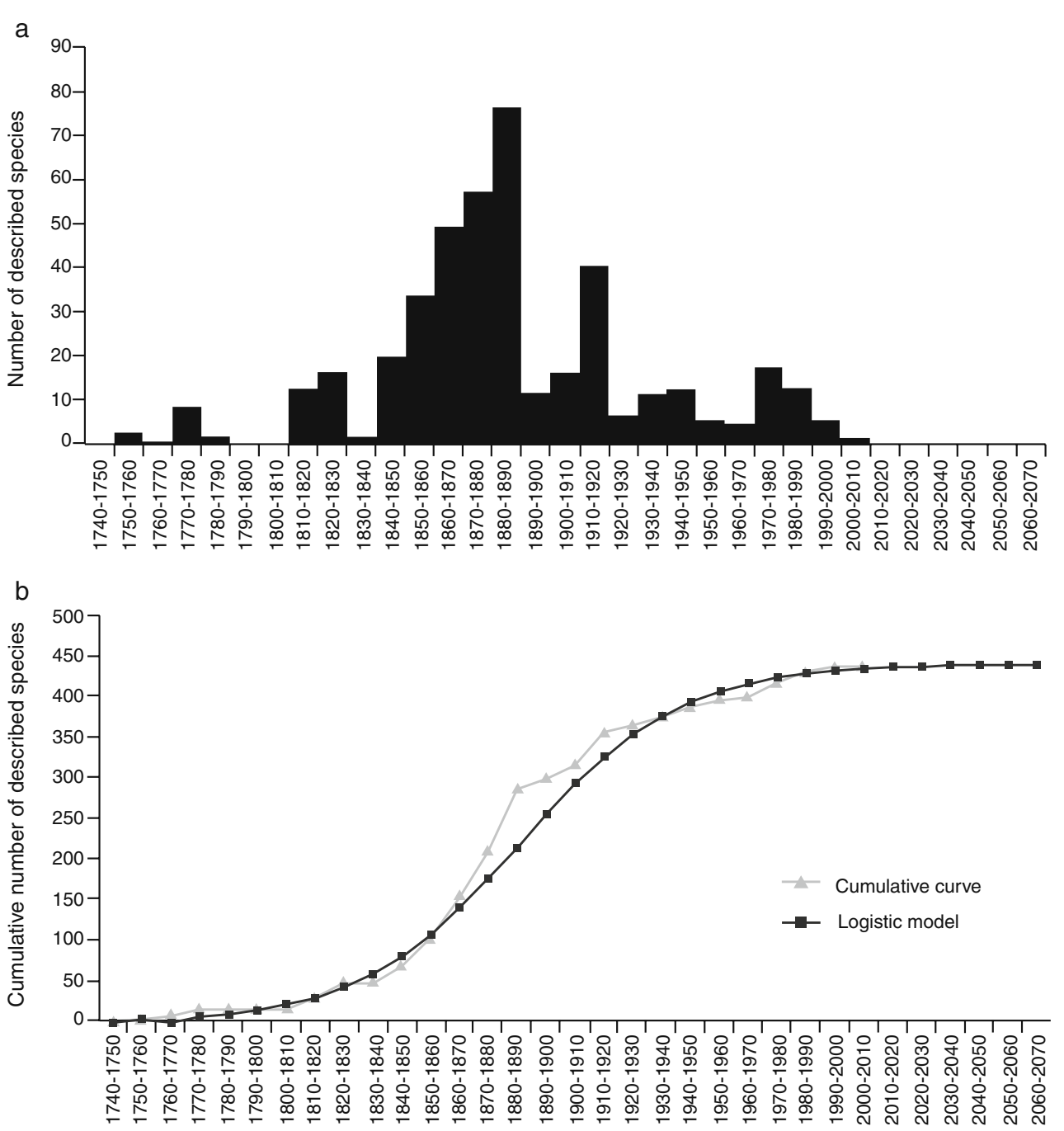

cryptic habitats ideal for the development of the Ophiuroidea, which is the most diverse in the region. Moreover, additional species will probably be described when the deep areas of the Caribbean are studied, altering the predictive species description curve in Fig. $2 b$.

Mexico, Belize, Panama, Colombia and Cuba exhibit the highest species diversity, due in part to the rich coastal habitats, which are the most diverse in the region (Spalding et al. 2001), and to intensity of research in these areas. Relative to species description and publications, Colombia has taken the lead, with a higher sampling effort along all of its Economic Exclusive Zone, with collections from shallow and deep waters (Borrero-Pérez et al. 2002a, b, 2008; Benavidez-Serrato et al. 2005). An important feature of the region is the presence of the Mesoamerican reef, in Mexico, Belize, Guatemala and Honduras. This area could be considered a diversity hot spot.

In terms of ecoregions, the Southwestern Caribbean is the richest (Fig. 6), due to its central location in the region, the current patterns, and the influence of species from the north and the south. The Western Caribbean and the Greater Antilles ecoregions are the most similar due to their proximity but also due to the influence of species from the Gulf of Mexico, Florida and Bahamas. On the other hand, the Southern and Eastern Caribbean ecoregions are influenced by the faunas from Guyana and Brazil. This can also help explain why Mexico and Colombia are located on opposite sides of the nMDS (Fig. 4), having faunal influences from two different regions. All the countries from one ecoregion are very similar in composition (Figs. 3, 4).

The Central American countries like Guatemala, Honduras, Nicaragua and Costa Rica, and the Lesser Antilles are the least studied. It is important to notice that in the case of the Central American countries, the social movements of the 1960s and 1970s shifted the attention to issues other other than science. This combined with the lack of economic resources, research institutions, and reduced science investments have resulted in this lack of knowledge. However, according to Fig. 1b, countries with low species numbers are probably undersampled, especially 

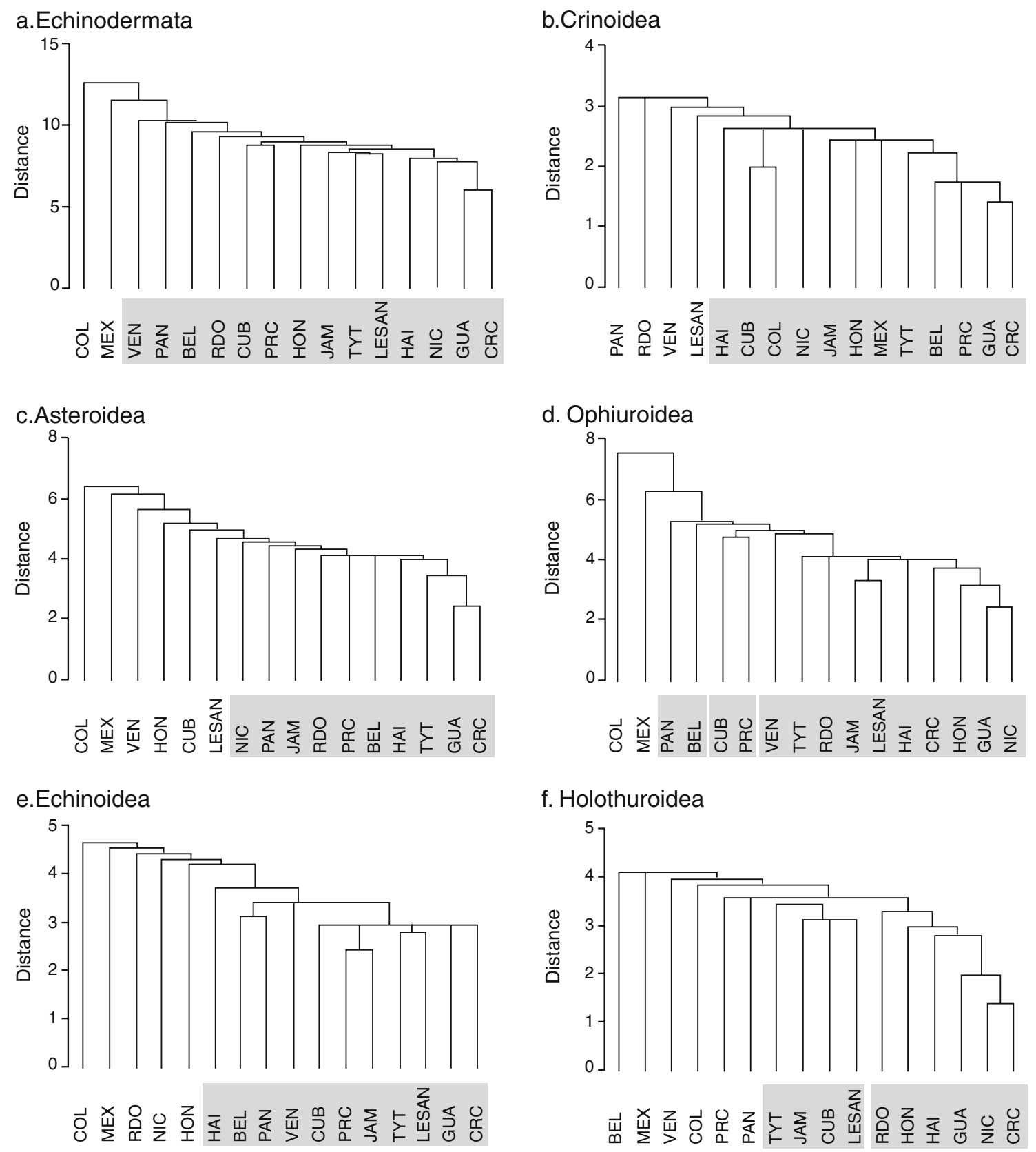

Fig. 3 Cluster tree (Euclidean distance) based on species presence/absence Bray-Curtis resemblance matrix: a Echinodermata, b Crinoidea, c Asteroidea, d Ophiuroidea, e Echinoidea, f Holothuroidea; between the Caribbean countries. Gray areas most similar countries

those in close proximity to highly diverse countries. Trinidad \& Tobago, the Lesser Antilles, Haiti, Jamaica, Guatemala, Honduras, Nicaragua and Costa Rica are likely undersampled, when compared with the number of species reported from neighboring countries (Fig. 1). However, it is necessary to look at these analyses with care, because in some cases it could reflect the reality of the species richness due to the small size of the coastal zone, the degraded state of some coasts from natural and anthropogenic disturbances, and the lack of complex coastal morphology and habitat diversity.
Along the Caribbean Sea, seven species of echinoderms (four holothuroids and three echinoids) are extracted for commercial use. Among them are the sea cucumbers Astichopus multifidus, Holothuria mexicana, Actinopyga agassizi, and Isostichopus badionotus, the last being the most intensely harvested (Toral-Granda 2008). Extractions occur primarily in Panama, Nicaragua, Colombia, Venezuela, Mexico and Cuba. The exploitation of sea cucumbers without the use of a calculated fisheries management approach is probably the biggest threat to their populations within the region. For many of the species under legal or 


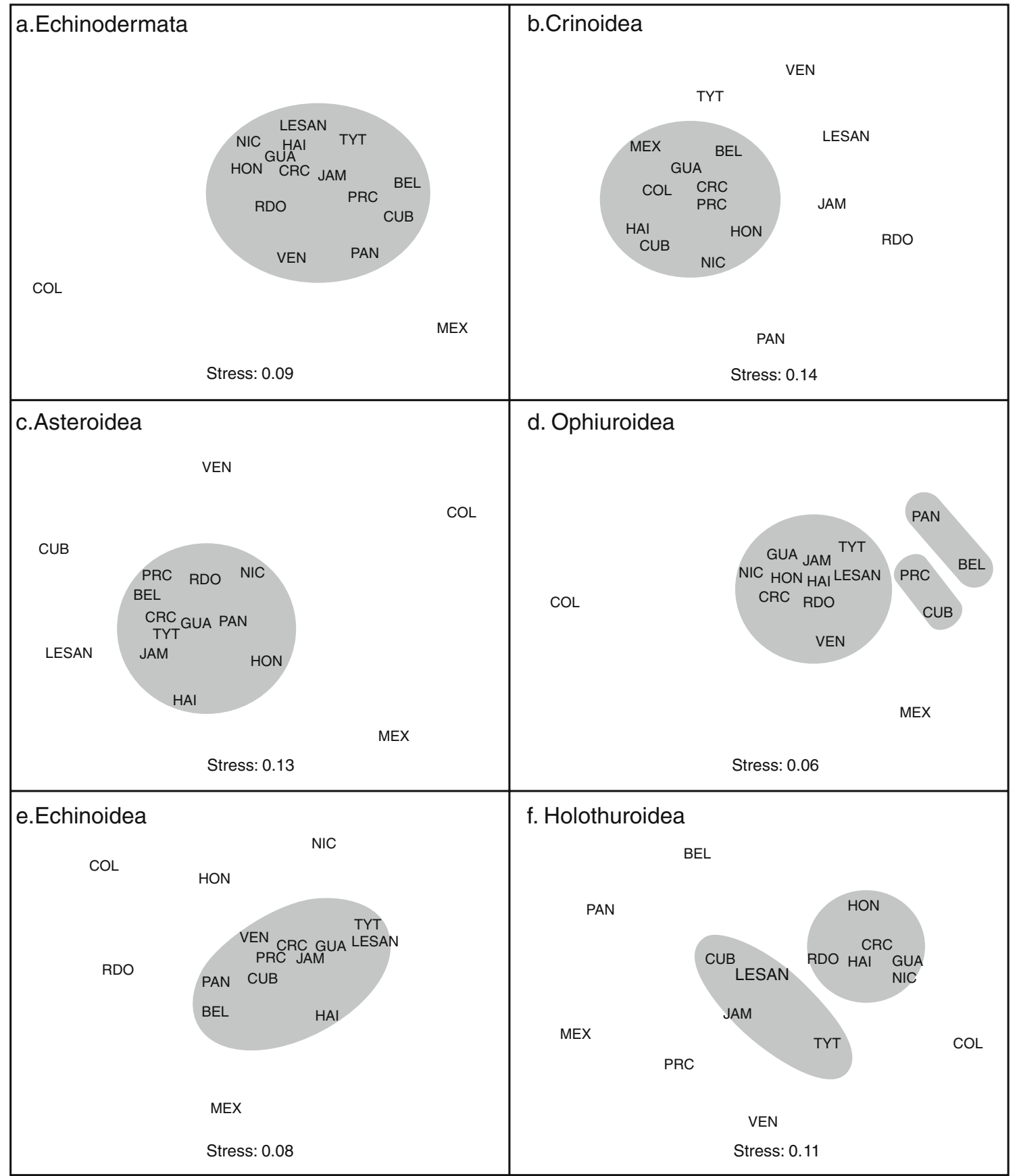

Fig. 4 Non-metric multiple dimensional scaling (NMDS) based on species presence/absence Bray-Curtis resemblance matrix: a Echinodermata, b Crinoidea, c Asteroidea, d Ophiuroidea, e Echinoidea, f Holothuroidea; between the Caribbean countries. Gray areas most similar countries

illegal fishing pressures there is little or no scientific information available on the biology, ecology, population abundance and dynamics (Toral-Granda 2008). Moreover, the situation is exacerbated because the majority of sea cucumber exploitations along the Caribbean (Buitrago and Boada 1996; Rodríguez-Millet and Pauls 1998; de la Fuente-Betancourt et al. 2001; Guzmán and Guevara $2002 \mathrm{~b}$ ) started with the consent of the local authorities, but without any knowledge about the ecology of the species
(Guzmán et al. 2003). In the case of Panama, this activity is now banned, due to overfishing in 1997, during which 750,000 sea cucumbers were extracted in 30 days (Guzmán and Guevara 2002b).

Along the Caribbean there are small sea urchin fisheries focused on Echinometra spp., Lytechinus variegatus and Tripnesutes ventricosus. Granada and Martinique sea urchin harvests are the largest (Williams 2002). In the Margarita and Coche islands, Venezuela, L. variegatus and $E$. 
Fig. 5 Taxonomic distinctness index: a average (delta: $\Delta^{+}$), and b their variation (lambda: $\Lambda^{+}$) of the Caribbean echinoderms. Continuous line $95 \%$ confidence limit, discontinuous line $\Delta^{+}$ average value

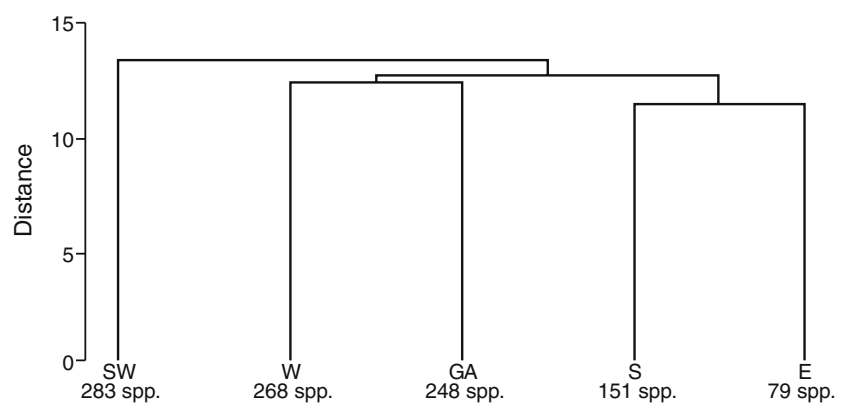

Fig. 6 Cluster tree (Euclidean distance) based on species presence/ absence Bray-Curtis resemblance matrix of echinoderms by ecoregion. $W$ Western Caribbean, SW Southwestern Caribbean, GA Greater Antilles, $E$ Eastern Caribbean, $S$ Southern Caribbean
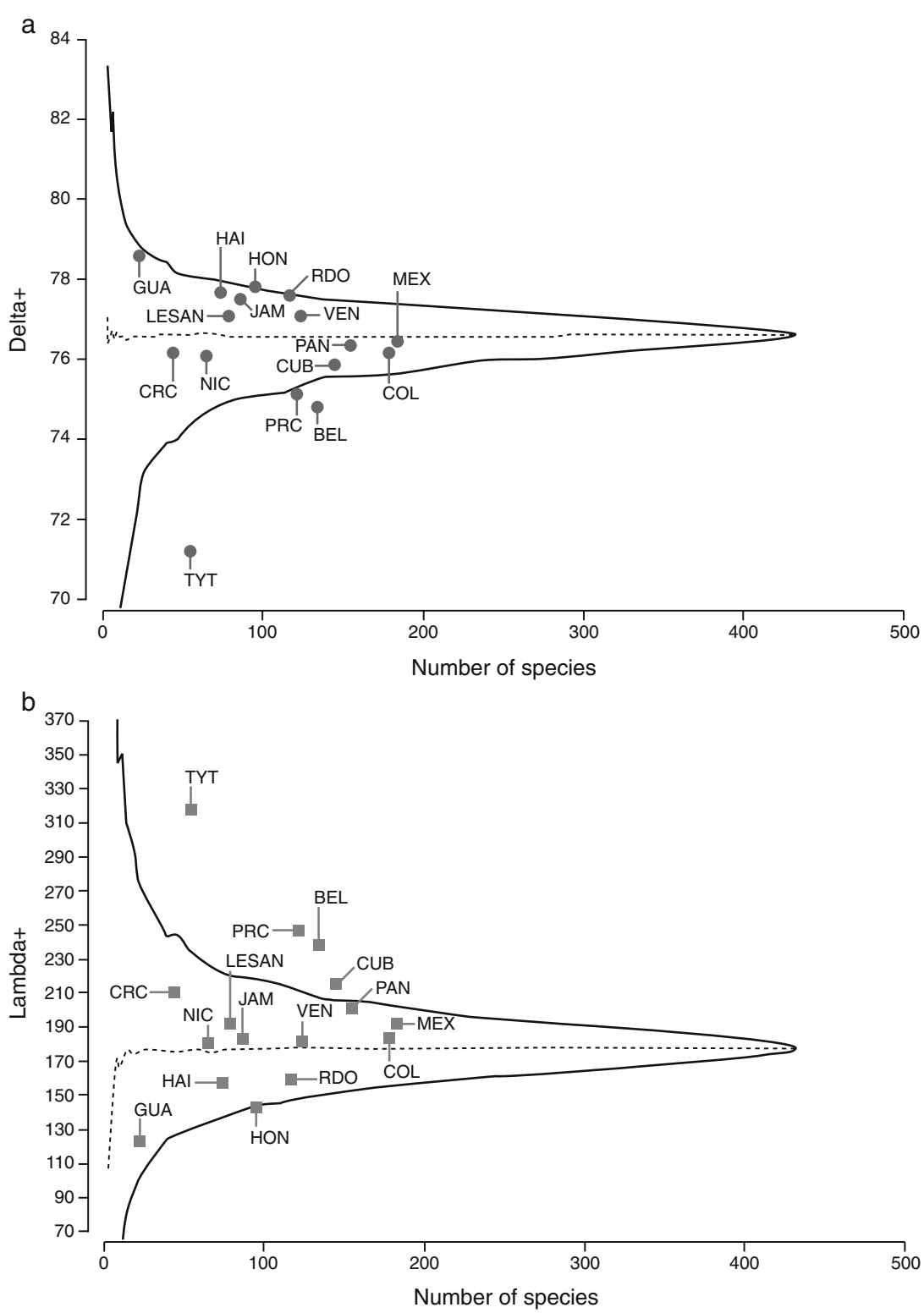

lucunter are extracted and processed on a small scale for human consumption (Gómez 1999). However, there is the fear that due to their naturally low population numbers these resources could be reduced by overfishing (Gómez and Gómez 2005).

In the case of the souvenir trade, Lunn et al. (2008) analysed the situation in Mexico, finding that annually 87,600 Oreaster reticulatus are extracted, with no regulation, and sold at prices between 1.8 and 60 US dollars. Similarly, Sloan (1984) indicated that this seastar might be under threat throughout the Caribbean, where some populations have been devastated. Mexico, Jamaica, Trinidad and Venezuela, among others, allow Oreaster extraction without apparent restrictions, which could increase demand in other countries (Guzmán and Guevara 2002a). 
Lunn et al. (2008) also mentioned the extraction of other echinoderms like Astropecten, Mellita and Tripnesutes as souvenirs in Mexico. However, there are no complete analyses of the exploitation of echinoderms in other places, like Colombia, Venezuela or Panama, where Oreaster as well as other echinoderms are extracted.

The lack of control in echinoderm extraction is a major threat in the Caribbean region. However, the greatest threats to this group of animals come from anthropogenic disturbances like sedimentation and coastal pollution. Sedimentation reduces recruitment success for some key species, such as sea urchins (i.e., Diadema antillarum; Vázquez-Domínguez 2003). Moreover, the loss of architectural complexity of the majority of coral reefs on the area (Alvarez-Filip et al. 2009), reduces the availability of substrate for recruitment and development. Agricultural pollution can produce endocrine disruptions in many species, slowing the recovery of critical populations (Rawlins et al. 1998). Coastal development has become a serious threat for endemic and cryptic species of ophiuroids in Colombia, Panama and Costa Rica, where the rock cavities made by sea urchins are being seriously degraded (Hendler 2005; Monroy-López and Solano 2005).

The research priorities for this group of animals in the Caribbean should be focused on the discovery of new species from deep waters, increased research in Central America and the Lesser Antilles, and increased ecological research in groups other than the echinoids. Future studies should also focus on (1) the role of marine protected areas for the recovery of key species, (2) population changes in fishing grounds, and (3) the impact of diseases in the region. Moreover, due to its rich biodiversity, relative to other tropical American waters, research and conservation efforts must be directed toward the preservation and conservation of that diversity, avoiding illegal extraction, enforcing controls, and improving coastal management.

Acknowledgements I am grateful to those who facilitated access to literature or access to museum collections. Specially, I am grateful to the Census of Marine Life-Caribbean, CONACYT (México), CONICIT-MICIT (Costa Rica). I also would like to thank P. Miloslavich, G. Díaz-Erales, M. Chávez, J. Cortés, B. Bezy and C. Fernández, whose contributions greatly enriched this paper. I appreciated the comments of the three anonymous reviewers. This publication is dedicated to Balú.

\section{References}

Abreu-Pérez M, Solís-Marín FA, Laguarda-Figueras A (2005) Catalogo de los equinodermos (Echinodermata: Asteroidea y Ophiuroidea) neritico-bentonico del Archipielago Cunabo. Rev Biol Trop 53(S3):29-52

Agassiz A (1869) Preliminary report on the Echini and starfishes dredged in deep water between Florida and Cuba Reefs, by L.H. de Pourtàles. Bull Mus Comp Zool 1:253-308
Alvarado JJ, Solís-Marín FA, Ahearn C (2008) Equinodermos (Echinodermata) del Caribe Centroamericano. Rev Biol Trop 56 (S3):37-55

Alvarado JJ, Solís-Marín FA, Ahearn C (2010) Echinoderm (Echinodermata) diversity in the Pacific coast of Central America. Mar Biodiv 40:(in press). doi:10.1007/s12526-009-0032-5

Alvarez-Filip L, Dulvy NK, Gill JA, Côté IM, Watkinson AR (2009) Flattening of Caribbean coral reefs: region-wide declines in architectural complexity. Proc Roy Soc B 276:3019-3025

Alvarez-Larrauri LR (1981) Listado preliminar de los Equinodermos de la costa Atlántica Colombiana. Bol Mus Mar 10:24-39

Bak RPM, Carpay MJE, de Ruyter van Steveninck ED (1984) Densities of the sea urchin Diadema antillarum before and after mass mortalities on the coral reefs of Curacao. Mar Ecol Prog Ser 17:105-108

Benavides-Serrato M (2006) Taxonomic list of the shallow water echinoderms of Puerto Rico with New information for La Parguera. Thesis, Universidad de Puerto Rico, San Pedro

Benavides-Serrato M, Borrero-Pérez GH (2000) Equinodermos de la franja superior del talud continental del Caribe Colombiano. Thesis, Universidad de Bogotá Jorge Tadeo Lozano, Bogotá

Benavidez-Serrato M, Borrero-Pérez GH, Solano OD, Navas GR (2005) Listado taxonomico de los asteroideos (Echinodermata: Asteroidea) de la plataforma y el talud superior del Caribe colombiano. Rev Biol Trop 53(S3):171-194

Borrero-Pérez GH, Benavides-Serrato M, Solano OD, Navas GR (2002a) Equinoideos (Echinodermata: Echinoidea) colectados en la franja superior del talud continental del Caribe Colombiano. Bol Inv Mar Cos 31:133-166

Borrero-Pérez GH, Solano OD, Benavides-Serrato M (2002b) Lista revisada de los erizos (Echinodermata: Echinoidea) del Mar Caribe Colombiano. Biota Colomb 3:141-148

Borrero-Pérez GH, Benavides-Serrato M, Solano OD, Navas GR (2008) Brittle-stars (Echinodermata: Ophiuroidea) from the continental shelf and upper slope of the Colombian Caribbean. Rev Biol Trop 56(S3):169-204

Brown-Saracino J, Peckol P, Curran HA, Robbart ML (2007) Spatial variation in sea urchins, fish predators, and bioerosión rates on coral reefs of Belize. Coral Reefs 26:71-78

Buitrago J, Boada JA (1996) La pesca de la holoturia Isostichopus badionatus en el oriente de Venezuela. Mem Soc Cienc Nat La Salle 146:33-40

Buitrago E, Lodeiros-Seijo C (2005) Producción de larvas y postlarvas del erizo verdiblanco del Caribe Lytechinus variegatus (Echinodermata: Echinoidea) en condiciones de cultivo. Rev Biol Trop 53(S3):319-328

Caycedo IE (1978) Holothuroidea (Echinodermata) de aguas someras en la costa norte de Colombia. An Inst Invest Mar Punta Betín 10:149-198

Caycedo IE (1979) Observaciones de los equinodermos en las Islas del Rosario. An Inst Invest Mar Punta Betín 11:39-47

Chesher RH (1970) Evolution in the genus Meoma (Echinoidea: Spatangoida) and a description of a new species from Panama. Bull Mar Sci 20:731-761

Chesher RH (1968) Lytechinus williamsi, a new sea urchin from Panama. Breviora 305:1-13

Chesher RH (1972) The status of knowledge of Panamanian Echinoids, 1971, with comments on other Echinoderms. Bull Biol Soc Wash 2:139-157

Clark HL (1901) The echinoderms of Porto Rico. US Fish Comm Bull 1900(2):231-263

Clark AM, Downey ME (1992) Starfishes of the Atlantic. Chapman \& Hall, London

Clarke KR, Warwick RM (2001) A further biodiversity index aplicable to specues list: variation in taxonomic distinctness. Mar Ecol Prog Ser 216:265-278 
Collins LS (1996) Environmental changes in Caribbean shallow waters relative to the closing of the Central American Isthmus. In: Jackson JBC, Budd AF, Coates AG (eds) Evolution and environment in tropical America. The University of Chicago Press, Chicago, pp 130-167

de la Fuente-Betancourt GM, Jesus-Navarrete A, Sosa-Cordero E, Herrero-Perezrul MD (2001) Assessment of the sea cucumber (Echinodermata; Holothuroidea) as potencial fishery resource in Banco Chinchorro, Quintana Roo, Mexico. Bull Mar Sci 68:59-67

Deichmann E (1926) Report of the holothurians collected by the Barbados-Antiqua Expedition. Stud Nat Hist Univ Iowa 11:9-31

Deichmann E (1930) The holothurians of the western part of the Atlantic Ocean. Bull Mus Comp Zool Harvard Univ 71:41-226

Deichmann E (1940) Report on the holothurians collected by the Harvard-Havana expeditions 1938 and 1939, with revision of the Molpadonia of the Atlantic Ocean. Mem Soc Cubana Hist Nat 14:183-240

Deichmann E (1963) Shallow water holothurians known from the Caribbean waters. Stud Fauna Curaçao 14:100-118

Del Valle-García R, Solís-Marín FA, Abreu-Pérez M, LaguardaFigueras A, Duran-Gonzalez A (2005) Catalogo de los equinodermos (Echinodermata: Crinoidea, Echinoidea, Holothuroidea) nerítico-bentónicos del Archipiélago Cubano. Rev Biol Trop 53 (S3):9-28

Del Valle-García R, Abreu-Pérez M, Rodríguez R, Solís-Marín FA, Laguarda-Figueras A, Durán-González A (2008) Equinodermos (Echinodermata) del occidente del Archipiélago SabanaCamagüey, Cuba. Rev Biol Trop 56(3):19-35

Devaney DM (1974) Shallow-water echinoderms from British Honduras, with a description of a new species of Ophiocoma (Ophiuroidea). Bull Mar Sci 24:122-164

Downey ME (1973) Starfishes from the Caribbean and the Gulf of Mexico. Smithsonian Contr Zool 126:1-158

Engel H (1933) Resultats Scientifiques du Voyage aux Indies Orientales Neerlandaises de LL. AA. RR. le Prince et la Princesse Leopold de Belgique. Holothuries. Mem Mus R Hist Nat Belg Hors Serie 3:1-42

Flores C, Martínez RA (1970) Status de la familia Goniasteridae (Asteroidea: Phanerozonia) en la región Oriental de Venezuela. Bol Inst Oceanogr Universidad de Oriente 9:3-8

Fonseca AC, Arrivillaga A (2003) Coral reefs of Guatemala. In: Cortés J (ed) Latin America Coral Reefs. Elsevier, Amsterdam, pp 159-169

Fontaine A (1953a) The shallow water echinoderms from Jamaica. Part I. The starfishes (Class Asteroidea). Nat Hist Notes Nat Hist Soc Jamaica 59:170-184

Fontaine A (1953b) The shallow water echinoderms from Jamaica. Part II. The brittle-stars (Class Ophiuroidea). Nat Hist Notes Nat Hist Soc Jamaica 59:197-206

Fontaine A (1953c) The shallow water echinoderms from Jamaica. Part IV. The sea cucumbers (Class Holothuroidea). Nat Hist Notes Nat Hist Soc Jamaica 60:29-33

Francisco V, Pauls SM (2008) Especies del orden Clypeasteroida (Echinodermata: Echinoidea) de las costas de Venezuela. Rev Biol Trop 56(S3):215-228

Gómez A (1999) Los recursos marinos renovables del Estado Nueva Esparta, Venezuela. Biología y pesca de las especies comerciales. Tomo I. Invertebrados y algas. Organización Gráficas Capriles, Caracas

Gómez O, Gómez A (2005) Desarrollo embrionario y larval de Lytechinus variegatus (Echinoidea: Toxopneustidae) en condiciones de laboratorio en la Isla de Margarita-Venezuela. Rev Biol Trop 53(S3):313-318

Gómez-Gaspar A (2002) Abundancia de erizo Lytechinus variegatus (Lamarck) en la costa norte, este y oeste de la Isla de Margarita (Venezuela). Biol Mar 53:15-20
Gonzalez DN, Solano OD, Navas G (2002) Equinodermos colectados por la expedición CIOH-INVEMAR-Smithsonian desde Cartagena al Golfo de Urabá, Caribe Colombiano. Bol Inv Mar Cos 31:85-132

Griffin SP, García RP, Weil E (2003) Bioerosión in coral reef communities in southwest Puerto Rico by the sea urchin Echinometra viridis. Mar Biol 143:79-84

Guzmán HM, Guevara C (2002a) Annual reproductive cycle, spatial distribution, abundance, and size structure of Oreaster reticulatus (Echinodermata: Asteroidea) in Bocas del Toro, Panama. Mar Biol 141:1077-1084

Guzmán HM, Guevara C (2002b) Population structure, distribution and abundance of three commercial species of sea cucumber (Echinodermata) in Panama. Carib J Sci 38:230-238

Guzmán HM, Guevara C, Hernandez IC (2003) Reproductive cycle of two commercial species of sea cucumber (Echinodermata: Holothuroidea) from Caribbean Panama. Mar Biol 142:271-279

Hadel VF, Monteiro AMG, Ditadi ASF, Tiago CG, Tommasi LR (1999) Filo Echinodermata. In: Migotto AE, Tiago CG (eds). Bidiversidade do Estado de São Paulo: Conhecimento Atual. Parte 3: Invertebrados Marinhos. São Paulo, pp 259-272

Hasbún CR, Lawrence AJ (2002) An annotated description of shallow water Holothurians (Echinodermata: Holothuroidea) from Cayos Cochinos, Honduras. Rev Biol Trop 50:669-678

Hendler G (1988) Western Atlantic Ophiolepis (Echinodermata: Ophiuroidea): a description of $O$. pawsoni new species, and key to the species. Bull Mar Sci 42:265-272

Hendler G (1995) New species of brittle stars from the western Atlantic, Ophionereis vittata, Amphioplus sepultus, and Ophiostigma siva, and the designation of a neotype for Ophiostigma isocanthum (Say) (Echinodermata: Ophiuroidea). Nat Hist Mus LA County Contr Sci 458:1-19

Hendler G (2005) Two new brittle star species of the genus Ophiothrix (Echinodermata: Ophiuroidea: Ophiothrichidae) from coral reefs in the southern Caribbean Sea, with notes on their biology. Carib J Sci 41:583-599

Hendler G, Pawson DL (2000) Echinoderms of the rhomboidal cays, Belize: biodiversity, distribution, and ecology. Atoll Res Bull 479:274-299

Hendler G, Miller JE, Pawson DL, Kier PM (1995) Sea stars, sea urchins, and allies. Smithsonian Institution Press, Washington DC London

Herrera-Moreno A, Betancourt L (2004) Especies de equinodermos recientes (Echinodermata: Crinoidea: Asteroidea: Ophiuroidea: Echinoidea y Holothuroidea) conocidas para la hispaniola. Rev Cienc Soc 3:506-533

Honey-Escandón M, Solís-Marín FA, Laguarda-Figueras A (2008) Equinodermos (Echinodermata) del Pacífico Mexicano. Rev Biol Trop 56(S3):57-73

Hotchkiss FHC (1982) Ophiuroidea (Echinodermata) from Carrie Bow Cay, Belize. In: Rützler K, Macintyre IG (eds) The Atlantic Barrier Reef ecosystem of Carrie Bow Cay, Belize, I Structure and communities. Smithsonian Intitution Press, Washington, pp $387-411$

Kier PM (1975) The echinoids of Carrie Bow Cay, Belize. Smithson Contrib Zool 206:1-45

Laguarda-Figueras A, Solís-Marín FA, Durán-González A, Ahearn CG, Buitrón-Sánchez BE, Torres-Vega J (2005) Equinodermos (Echinodermata) del Caribe Mexicano. Rev Biol Trop 53 (S3):109-122

Lessios HA (1981a) Reproductive periodicity of the echinoids Diadema and Echinometra on the two coast of Panama. J Exp Mar Biol Ecol 50:47-61

Lessios HA (1981b) Divergence in allopatry: molecular and morphological differential between sea urchins separted by the Isthmus of Panama. Evolution 35:618-634 
Lessios HA (1998) Shallow water echinoids of Cayos Cochinos, Honduras. Rev Biol Trop 46(S4):95-101

Lessios HA (2005) Diadema populations twenty years following mass mortality. Coral Reefs 24:125-127

Lessios HA, Robertson DR, Cubit JD (1984) Spread of Diadema mass mortality throught the Caribbean. Science 226:335-337

Lessios HA, Kessing BD, Pearse JS (2001) Population structure and speciation in tropical seas: global phylogeography of the sea urchin Diadema. Evolution 55:955-975

Lessios HA, Kane J, Robertson DR (2003) Phylogeography of the Pantropical sea urchin Tripneustes: contrasting patterns of population structure between oceans. Evolution 57:2026-2036

Lunn KE, Villanueva-Noriega MJ, Vincent ACJ (2008) Souvenirs from the sea: an investigation into the curio trade in echinoderms from Mexico. Traffic Bull 22:19-32

Lyman T (1869) Preliminary report on the Ophiuridae and Astrophytidae dredged in deep water between Cuba and the Florida Reef by L.F. de Pourtàles, Assist. U.S. Coast Survey. Bull Mus Comp Zool Harvard College 1:309-354

Macurda DB Jr (1982) Shallow-water Crinoidea (Echinodermta) from Carrie Bow, Belize. In: Rütsler K, Macintyre IG (eds) The Atlantic Barrier Reef ecosystem at Carrie Bow Cay, Belize, I Structure and communities. Smithsonian Institutions Press, Washington, pp 413-416

Mah CL (2009) World Asteroidea database. http://www.marinespecies. org/asteroidea. Accessed 25 November 2009

Maluf LY (1991) Echinoderm fauna of the Galápagos Islands. In: James MJ (ed) Galápagos marine invertebrates: taxonomy, biogeography, and evolution in Darwin's islands. Plenum Press, New York, pp 345-367

Martínez A (1987) Equinoideos y Asteroideos de Venezuela. Bol Inst Oceanogr Univ Oriente 26:153-164

Martínez A (1989) Holoturoideos (Echinodermata, Holothuroidea) de la región nor-oriental de Venezuela y algunas dependencias federales. Bol Inst Oceanogr Venezuela Univ Oriente 28:105-112

Martínez A, Mago HA (1975) Contribución al conocimiento de los holoturoideos (Holoturoidea: Echinodermata) de la región oriental de Venezuela. Bol Inst Oceanogr Univ Oriente 14:187-197

Meyer DL (1973) Distribution and living habits of comatulid crinoids near Discovey Bay, Jamaica. Bull Mar Sci 23:244-259

Meyer DL, Macurda DB Jr (1976) Distribution of shallow-water crinoids near Santa Marta, Colombia. Mitt Inst Colombo-Alemán Invest Cient 8:141-156

Meyer DL, Messing CG, Macurda DB Jr (1978) Zoogeography of tropical western Atlantic Crinoidea (Echinodermta). Bull Mar Sci 28:412-441

Miller JE, Pawson DL (1984) Holothurians (Echinodermata: Holothuroidea). Memoirs of the Hourglass Cruises 7(1):1-79

Miloslavich P, Klein E (2005) Linking marine biodiversity research and conservation in the Caribbean. In: Miloslavich P, Klein E (eds) Caribbean marine biodiversity: the known and the unknown. DEStech, Lancaster, pp 6-23

Monroy-López M, Solano OD (2005) Estado poblacional de Echinometra lucunter (Echinodermata: Echinometridae) y su fauna acompañante en el litoral rocoso del Caribe Colombiano. Rev Biol Trop 53(S3):291-297

Montealegre-Quijano S, Gómez-Gaspar A (2005) Ciclo reproductivo de Lytechinus variegatus (Echinoidea: Toxopneustidae) en el sur de la Isla Margarita, Venezuela. Rev Biol Trop 53(S3):305-312

Mumby PJ, Hedley JD, Zychaluk K, Harborne AR, Blackwell PG (2006) Revisiting the catastrophic die-off of the urchin Diadema antillarum on Caribbean coral reefs: fresh insights on resilience from a simulation model. Ecol Mod 196:131-148

Ogden JC, Brown RA, Salesky N (1973) Grazing by the echinoid Diadema antillarum Philippi: formation of halos around West Indian patch reefs. Science 182:715-717
Parker DA, Shulman MJ (1986) Avoiding predation: alarm responses of Caribbean sea urchins to simulated predation on conspecific and heterospecific sea urchins. Mar Biol 93:201-208

Pawson DL (2007) Phylum Echinodermata. Zootaxa 1668:749-764

Pawson DL, Vance DJ, Ahearn C (2001) Western Atlantic sea cucumbres of the Order Molpasdiida (Echinodermata: Holothuroidea). Bull Biol Soc Wash 10:311-327

Pawson DL, Vance DJ, Messing CG, Solís-Marín FA, Mah CL (2009) Echinodermata of the Gulf of Mexico. In: Felder DL, Camp DK (eds) Gulf of Mexico: origin, waters, and biota. Vol. 1, Biodiversity. Texas A\&M University Press, College Station, pp 1177-1204

Price ARG, Keeeling MJ, O'Callaghan CJ (1999) Ocean-scale patterns of 'biodiversity' of Atlantic asteroids determined from taxonomic distinctness and other measures. Biol J Lin Soc 66:187-203

Rawlins BG, Ferguson AJ, Chilton PJ, Arthurton RS, Rees JG, Baldock JW (1998) Review of agricultural pollution in the Caribbean with particular emphasis on small island developing states. Mar Pollut Bull 36:658-668

Rivera-Monroy VH, Twilley RR, Bone D, Childers DL, CoronadoMolina RC, Feller IC, Herrera-Silveira J, Jaffe R, Mancera E, Rejmankova E, Salisbury JE, Weil E (2004) A conceptual framework to develop long-term ecological research and mangement objectives in the wider Caribbean region. Bioscience $54: 843-856$

Rodríguez AM (1969) Contribucion al conocimiento de la familia Brissidae (Echinoidea: Spatangoidea) en Venezuela. Bol Inst Oceanogr Univ Oriente 8:57-63

Rodríguez AM (1973) Contribucion al estudio de los holothuroideos de Venezuela. Bol Inst Oceanogr Univ Oriente 12:41-50

Rodríguez-Millet E, Pauls SM (1998) Sea cucumbers fisheries in Venezuela. In: In: Mooi R, Telford M (eds) Echinoderms. Balkema, San Francisco, pp 513-516

Sammarco PW (1980) Diadema and its relationship to coral spat mortality: grazing, competition and biological disturbance. J Exp Mar Biol Ecol 45:245-472

Sammarco PW (1982a) Echinoid grazing as a structure force in coral communities: whole reef manipulations. J Exp Mar Biol Ecol 61:31-55

Sammarco PW (1982b) Effects of grazing by Diadema antillarum Phillipi (Echinodermata: Echinoidea) on algal diversity and community structure. J Exp Mar Biol Ecol 65:83-105

Schoppe S (1996) Ophiothrix synoecin a new species (Echinodermata: Ophiuroidea) from the Caribbean coast of Colombia. Bull Mar Sci 58:429-437

Scoffin TP, Stearn CW, Boucher D, Frydl P, Hawkins CM, Hunter JG, MacGeachy JK (1980) Calcium carbonate budget of fringing reef of the West coast of Barbados. Part II. Erosion, sediments and internal structure. Bull Mar Sci 30:475-508

Serafy DK (1970) A new species of Clypeaster from the Gulf and Caribbean and key to the species in the tropical northwestern Atlantic (Echinodermata: Echinoidea). Bull Mar Sci 20:662-677

Sloan NA (1984) Echinoderm fisheries of the world: a review. In: Keegan $\mathrm{BF}$, O'Connor BD (eds) Proceedings of the 5th International Echinoderm Conference. A.A. Balkema, Galway, pp 109-124

Solís-Marín FA, Laguarda-Figueras A, Durán A, Ahearn C, TorresVega J (2005) Equinodermos (Echinodermata) del Golfo de California, México. Rev Biol Trop 53(S3):123-137

Spalding MD (2004) A guide to the coral reefs of the Caribbean. University of California Press, Berkeley

Spalding MD, Ravilious C, Green EP (2001) World atlas of coral reefs. University of California Press, Los Angeles

Spalding MD, Fox HE, Allen GR, Davidson N, Cerdaña ZA, Finlayson M, Halpern BS, Jorge MA, Lombana A, Lourie SA, Martin KD, McManus E, Mollnar J, Recchia CA, Robertson J (2007) Marine ecoregions of the world: a bioregionalization of coastal and shelf areas. Bioscience 57:573-583 
Steiner SCC, Williams SM (2006) The density and size distribution of Diadema antillarum in Dominica (Lesser Antilles): 2001-2004. Mar Biol 149:1071-1078

Stöhr S, O’Hara T (2007) World Ophiuroidea database. http://www. marinespecies.org/ophiuroidea. Accessed 25 November 2009

Suárez AM (1974) Lista de equinodermos Cubanos recientes. Investig Mar 8:1-72

Toral-Granda V (2008) Population status, fisheries and trade of sea cucumbers in Latin America and the Caribbean. In: Toral-Granda V, Lovatelli A, Vasconcellos M (eds) Sea cucumbers. A global review and trade. Technical paper No. 516, FAO Fisheries and Aquaculture, Rome, pp 213-229

Vázquez-Domínguez E (2003) Diversidad y distribución de crustáceos y equinodermos y su relación con niveles de sedimentación en arrecifes coralinos. Rev Biol Trop 51:183-194
Weil E, Torres JL, Ashton M (2005) Populations characteristics of the sea urchin Diadema antillarum in La Parguera, Puerto Rico, 17 years alter the mass mortality event. Rev Biol Trop 53 (S3):219-231

Williams H (2002) Sea urchin fisheries of the world: a review of their status, management strategies and biology of the principal species. Department of Primary Industries, Waste and Environment, Tasmania

Zapata FA, Robertson DR (2007) How many species of shore fishes are there in the Tropical Eastern Pacific? J Biogeogr 34:38-51

Zigler KS, Lessios HA (2004) Speciation on the coasts of the new world: phylogeography and the evolution of bindin in the sea urchin Lytechinus. Evolution 58:1225-1241

Zoppi de Roa E (1967) Contribución al estudio de los equinodermos de Venezuela. Acta Biol Venez 5:267-333 